\title{
Antivirals in medical biodefense
}

\author{
J. J. Bugert ${ }^{1} \oplus \cdot$ F. Hucke ${ }^{1} \cdot$ P. Zanetta ${ }^{1} \cdot$ M. Bassetto ${ }^{2} \cdot$ A. Brancale $^{3}$
}

Received: 27 July 2019 / Accepted: 20 January 2020 / Published online: 19 February 2020

(c) Springer Science+Business Media, LLC, part of Springer Nature 2020

\begin{abstract}
The viruses historically implicated or currently considered as candidates for misuse in bioterrorist events are poxviruses, filoviruses, bunyaviruses, orthomyxoviruses, paramyxoviruses and a number of arboviruses causing encephalitis, including alpha- and flaviviruses. All these viruses are of concern for public health services when they occur in natural outbreaks or emerge in unvaccinated populations. Recent events and intelligence reports point to a growing risk of dangerous biological agents being used for nefarious purposes. Public health responses effective in natural outbreaks of infectious disease may not be sufficient to deal with the severe consequences of a deliberate release of such agents. One important aspect of countermeasures against viral biothreat agents are the antiviral treatment options available for use in post-exposure prophylaxis. These issues were adressed by the organizers of the 16th Medical Biodefense Conference, held in Munich in 2018, in a special session on the development of drugs to treat infections with viruses currently perceived as a threat to societies or associated with a potential for misuse as biothreat agents. This review will outline the state-of-the-art methods in antivirals research discussed and provide an overview of antiviral compounds in the pipeline that are already approved for use or still under development.
\end{abstract}

Keywords Medical biodefense $\cdot$ Antiviral $\cdot$ BSL3/4 viral pathogens

\section{Introduction}

Antiviral compounds effective in infections caused by tropical and vector-borne viruses were a neglected topic of international antivirals research until very recently. A number of compounds are now in clinical trials, and very few have received regulatory approval, or have made it to the market.

This review refers to a presentation given by the authors at the 16th Medical Biodefense Conference held in Munich in 2018 and is intended to widen the view on the thematic issue with a special focus on biodefense-related aspects.

Edited by Lothar Zöller.

J. J. Bugert

Joachim1Bugert@bundeswehr.org

1 Bundeswehr Institute for Microbiology, Neuherbergstraße 11, 80937 Munich, Germany

2 Department of Chemistry, Swansea University, Swansea SA2 8PP, UK

3 Medicinal Chemistry, School of Pharmacy and Pharmaceutical Sciences, Cardiff University, Cardiff CF10 3NB, UK

\section{Biodefense relevance}

While infections with arthropod-borne and tropical viruses are fairly common in nature, severe outcomes are, with a few exceptions, very rare. Therefore, countermeasures against such unlikely events, especially in the developed world, are regarded as giving little or no return on investments and are sidelined by grant driven research and manufacturers. While this is a legitimate point of view for academia and the pharmaceutical industry, governments have to consider countermeasures against rare agents released, or threatened to be released deliberately by individuals or groups aiming to cause maximum societal disruption and chaos. For such events governments have to prepare credible countermeasures in order to be able to provide prophylaxis, isolation, and treatment for large numbers of exposed and infected individuals. The basis of all considerations on countermeasures and biothreat preparedness is an agent-related risk assessment, which includes numerous criteria like availability of stocks or samples for potential perpetrators, ease of handling, pathogenicity, transmission pathways, tenacity, availability of vaccines, antivirals, and others. This requires research into these countermeasures, including the development, testing 
and stockpiling of vaccines and antiviral drugs, particularly for dangerous biological agents. This review will focus on viral agents that fit into this category, briefly discussing their relevance for public health and biodefense, mode of action, and give an overview of treatment options available or in the pipeline.

\section{Public health relevance}

Viral hemorrhagic fevers (VHFs) cause the highest mortality in human hosts among all known viral agents. Encephalitides and severe respiratory infections caused by a range of viruses are other diseases with often severe clinical outcomes. The recent emergence of such infections from geographical hotspots is mainly a consequence of the rapid development of ground and air transport. Vector-borne infections are also affected by climate change. Large-scale outbreaks were first described for Monkeypox virus in central Africa in the 1970s [117], while outbreaks of mosquitoborne Chikungunya virus [85] and Dengue virus infections in the Indian Ocean islands were seen mostly in the twentyfirst century [124]. The historic Ebola outbreak in West Africa in 2013-2014, followed by a more recent one in the Republic of Congo with 1891 fatalities [37], has attracted extensive media attention. The rapid and uncontrolled spread of Ebola fever in Africa has been considered as a threat for the national security of developed countries with regard to the risk of imported cases but also for economic reasons. The Bundeswehr Institute of Microbiology (IMB) was involved in the international effort to contain Ebola fever in West Africa during the 2014-2016 outbreak [120]. The institute also runs a research program for antiviral drug development and hosts the biennial Medical Biodefense Conference (MBDC). Antiviral compounds and their possible role in biodefense were a special theme during the MBDC in 2018. The selection of topics with a focus on pox-, alpha- and flaviviruses was guided by the NATO AMedP-6 'Handbook on the medical aspects of nuclear, biological and chemical (NBC) defensive operations-Part II.' Smallpox, albeit eradicated in nature, continues to be perceived as a threat for several reasons, one of them being the risk that variola virus might be brought back with the methods of synthetic biology. Military forces and first responders in many countries were revaccinated in the early 2000s for fear that Iraq might have weaponized smallpox virus (which it had not, as was revealed later on). Emergency plans were developed to deal with a deliberate release. While no licensed drug was available at the time to treat infections with variola virus, a drug effective against orthopoxviruses, tecovirimat, has recently been approved by the United States Federal Drug Administration [55].

Smallpox as an exclusively human infection was eradicated by vaccination, but this is impossible for zoonoses like yellow fever, which has a number of non-human reservoir hosts. This is an important distinction, and in the case of an acute zoonotic viral infection, post-exposure antiviral treatment of the unvaccinated is a potentially lifesaving option in need of further development. Unfortunately, the public health repository of antiviral countermeasures for such infections is woefully small.

VHFs are caused by infection with RNA viruses. The standard of treatment for RNA virus infections where it shows efficacy, is ribavirin, developed in 1963 [32]. Where possible, early start of treatment of acute virus infections gives the best results and, in this context, accurate and rapid virus diagnosis is essential. The crucial role of a well-organized public health system and classic quarantine approaches was demonstrated in the recent Ebola outbreaks in West- and Central Africa. However, the need for new antiviral agents had generally been recognized and been reviewed by David Freestone as early as 1985 [47]. While many virus infections are asymptomatic, new or improved antiviral drugs are needed for the prevention and/or treatment of a number of significant conditions caused by viruses which at present cannot be controlled by alternative measures, including vector control, immunization and treatment with existing antiviral drugs. The need for specialized BSL-3/BSL-4 facilities with trained personnel for experiments with life viruses, and animal challenge, has further restricted research to a few high-security sites worldwide. As a result, there are no FDAapproved antivirals for Ebola or the causative viral agents of many other viral hemorrhagic fevers, viral encephalitides, and respiratory infections. Few therapeutic interventions are available except for supportive therapy.

In the following sections we will give a summary of the antivirals session held during the MBDC 2018, as well as an overview of antiviral drug development methodologies and selected experimental antivirals designed for potential biothreat agents.

\section{MBDC 2018: antivirals session}

After an introduction on the chances and challenges encountered in the development of novel antivirals (BrancaleMBDC-2018-GO1), a discussion on the current conditions in UK/EU research networks, obstacles at the interface between research and industry, and preparedness for the treatment of infections with biodefense-related viruses followed. Further contributions outlined the methodical approach to antivirals design and biological evaluation (Fig. 1). Using examples from chemists present at the meeting, the structural approach (Step 1; Bassetto-MBDC-2018-GO1), based on in silico dynamic models of antivirals targets, i.e., small-molecule inhibitors of polymerases, proteases, methyltransferases, and ProTide-based improvements of antiviral nucleosides 
Fig. 1 Methodical approach to antivirals design and biological evaluation
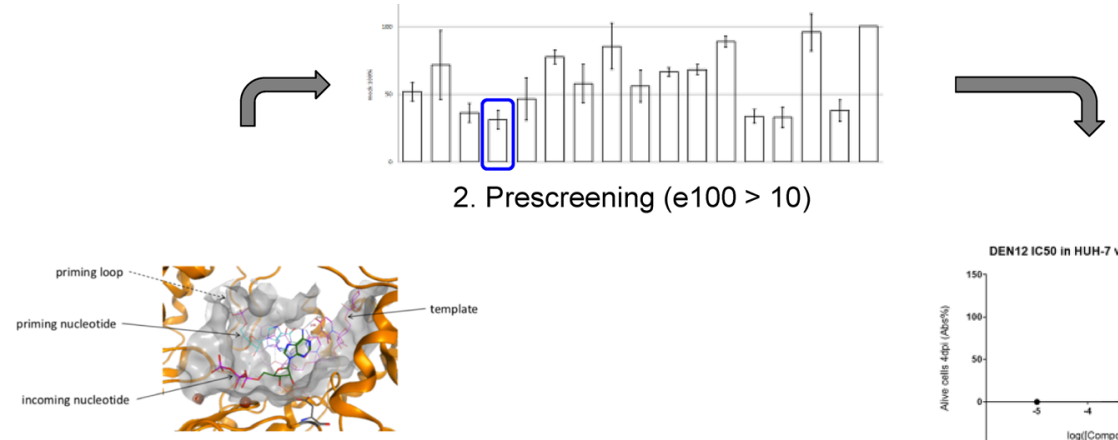

1. In silico preselection $\left(\mathrm{e}^{10^{6}}>100\right)$ $\mathrm{e}=$ expected reduction

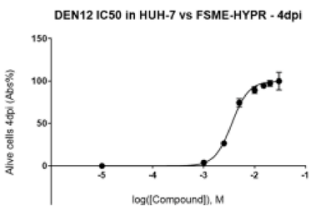

3. Selective Index $(e 10>1)$ IC50 / CC50 and target validation

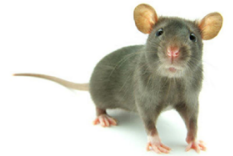

5. Animal model (e1 of 10$)$ going forward to clinical trials

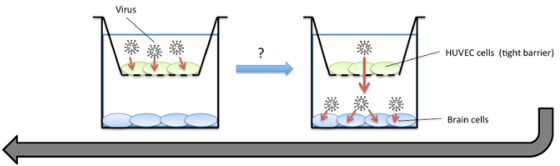

(4. Functional / barrier model) predictive for in vivo activity
[98, 132], were explained in detail. The dynamic models are based on solved NMR structures of protein targets. The preselection of virtual candidate antiviral compounds in in silico models against viral protein targets reduces the number of compounds by four magnitudes $\left(10^{6}\right.$ library $\rightarrow 10^{2}$ selected candidates). The compounds are then synthesized, shipped and compared at a standard concentration $(10 \mu \mathrm{M}$ at IMB) for comparative effectiveness and toxicity in organotypical cell lines against a panel of viruses of interest for the biodefense community, including alpha-, bunya-, filo-, flavi-, ortho-/paramyxo-, and poxviruses. Hit compounds with high efficacy and low toxicity are identified (Step 2). This is followed by $\mathrm{IC}_{50} / \mathrm{CC}_{50}$ evaluation (Step 3) of emerging hit to lead compounds, aiming for selective indices $>30$ in sensitive (e.g., Huh-7 hepatoma cells) and organotypical cell lines selected for the pathogenic traits of the viruses of interest (e.g., U138 glioblastoma cells for encephalitis viruses). This usually results in another reduction of candidate numbers by one to two magnitudes. To confirm drug targets, target validation is then carried out, either by the use of enzymatic assays for viral enzyme targets (SilvestriMBDC-2018-GO3) or by induction of resistant virus strains showing resistance mutations in the antiviral target areas, as shown with tecovirimat (ST-246) for orthopoxviruses. This concludes the classical in vitro evaluation of antiviral drug candidates. The winnowing process up to this point leads to a reduction ratio of six magnitudes $\left(10^{6}\right.$ to 1$)$. If in vitro toxicity is minimal, the compounds go straight into pharmacokinetics testing (rodent models), and into animal models of viral infections (Step 5). Here a dramatic rate of attrition leads to only one out of ten compounds tested in animal models making it into phase I clinical studies [79].
To further select compounds prior to animal testing, complex infection models, including in vitro 3D models, are currently the focus of much research in the antivirals field [77]. Functional models of virus infection at barriers, and the effect of antivirals on the virus passing the barrier, give an indication of antiviral effects on typical viral pathogenesis, e.g., encephalitis viruses that are being tested on models of the blood brain barrier (Step 4; Hurler-MBDC-2018-GP1). A successful prediction by in vitro functional models of antivirals efficacy in vivo, particularly using primary human organotypic cells, would also result in a significant reduction of unsuccessful drug testing in animal models. The evaluation cycle described above follows the general considerations as outlined by Huggins et al. for Ebolavirus (EBOV) in 1999 [64], with the addition of in silico design with dynamic models for compound preselection, which had not yet been available at that time, and represents a methodical approach to antivirals design and development. This approach is used by groups active in the field and is also the basis of the 'Antivirals Platform' collaboration between Cardiff University and IMB into prophylaxis and treatment of infections caused by viral biothreat agents, which is funded by SER CYMRU/ MRC and IMB's basic funding. The platform established comprises all steps from molecular design to in vitro testing in complex infection models. Talks at MBDC 2018 included different examples of this approach towards antiviral drug discovery: in silico design of small nucleosidic antivirals and prodrugs against arboviruses (Bassetto-MBDC-2018-GO2), Cima-4, Den-12, MB-124, tick borne encephalitis (TBEV) polymerase inhibitor nucleoside analogues with superior activity in the central nervous system (CNS) cells compared to sofosbuvir (Bugert-MBDC-2018-GO3), novel protease 
inhibitors for Zika virus as surrogate virus for other flaviviruses using an enzymatic assay for target validation as well as a Zika mouse model (Silvestri-MBDC-2018-GO4), and BB4-D9, a dandelion natural extract antiviral against poxviruses (Zanetta-MBDC-2018-GO5). FDA approval of oral TPOXX® (Tecovirimat/ST-246®), a F13L morphogenesis inhibitor of orthopoxviruses, was reported in the poxvirus session (Grosenbach-MBDC-2018-HO2). Posters provided meaningful examples of the evaluation cycle, with contributions on live cell imaging of virus-infected cells for antivirals testing in a model of the blood brain barrier (Hurler-MBDC-2018-GP2), a novel polymerase-inhibiting CHIKV antiviral (MB-70, Hucke-MBDC-2018-GP4), a NS4a autophagy testing system for flaviviruses (TscherneMBDC-2018-GP5), and MoA studies on Cf2642 inhibiting macropinocytosis of measles and poxviruses for use as synergistic cell-targeting antiviral along with virus-specific compounds (Narayan-MBDC-2018-GP6).

\section{Antivirals: FDA approved and experimental}

Complementing the recent review by De Clercq and Li [32] this section will focus on small-molecule antiviral compounds and discuss a selection of compounds that are either FDA approved or lately proved effective against viruses associated with a biothreat risk in in vitro experiments, animal or phase I-III clinical studies. Subsections give a brief overview of the viral agents in the order of relevance for biodefense, the FDA-approved treatment options, and antivirals in development, with top candidates highlighted in yellow in Table 1, which lists virus-specific compounds in the same order of relevance, detailing compound class, target and stage of development.

\section{Poxviridae}

Variola virus (smallpox virus), a member of the orthopoxvirus (OPV) genus of the family poxviridae, was used in the 18th century as a biological warfare agent by British and American forces in North America [36], and remains on the top of the list of biological threat agents for warfare or bioterrorism $[35,107]$. Effective vaccines and FDAapproved antivirals exist and could be used to control a deliberate release. Variola virus (VariolaV), which only infects humans, was declared eradicated in 1980, after a global vaccination campaign. Handling of VariolaV requires BSL-4 containment. Virus stocks are officially kept in only two designated laboratories in Russia and the US. Monkeypox virus (BSL-3), a zoonotic agent causing sequelae similar to smallpox but less fatal, is endemic in central Africa (Democratic Republic of Congo; DRC); recent introductions to the UK were travel-related. Poxviruses are transmitted by contact infection and via the respiratory tract, causing a systemic infection in humans and animals. Smallpox virus infection leads to a fatal multiorgan failure syndrome within 7-14 days, in complicated cases with a hemorrhagic syndrome and CNS involvement. Smallpox has played a role in large-scale epidemics in history and its causative agent continues to be considered a potential biological warfare agent [35]. Orthopoxviruses (OPV) are ovoid-shaped enveloped viruses with Group I double-stranded (ds) DNA genomes, replicating via a virus-encoded DNA polymerase, an antivirals target, in the cytoplasm of infected cells [42]. Poxviruses enter cells by macropinocytosis, but a poxvirusspecific receptor is still elusive [100]. Anti-poxvirus drugs. One of the first effective drugs in clinical use as a parenteral treatment in severe OPV infections was cidofovir, a bisphosphonate developed at REGA, in Belgium $[31,35]$ ) and FDA approved against human cytomegalovirus (HCMV). The ether lipid analogue brincidofovir (CMX001), a prodrug of cidofovir, has shown efficacy in small animal models and is awaiting FDA approval $[26,44,56,115,116,118$, 139]. The F13L virus egress inhibitor tecovirimat (ST246, TPOXX®) has been independently developed to treat smallpox infections and has been FDA approved since 2018. Tecovirimat has recently been used to treat non-human primates infected with variola, and humans exposed to OPV $[55,104,118,146]$. Tecovirimat (TPOXX $®)$ is currently stockpiled in the US and production for similar stockpiles in Europe is planned. Anti-poxvirus drugs effective in animal models are reviewed in more detail elsewhere [133]. Further candidate anti-poxvirus drugs include kinase inhibitors imatinib (Gleevec/STI-571; [122, 123]) and olomoucine [61], terameprocol [119], mitoxandrone [5], the membrane targeting ddBCNA cf2642 [99], bisbenzimide derivatives [151], FC-6407, a OPV D4 processivity factor mimic [111], and a number of natural extracts that have shown interesting antiviral activity against OPV in in vitro infection models [27, 153] (Table 1).

\section{Filoviridae}

Filoviruses are category A select agents, World Health Organization risk group 4 pathogens, high on the list of potential biological threat agents [107] and their handling requires BSL-4 containment. In nature they infect primates, pigs and bats (free-tailed and fruit bats) and are transmitted to human hosts by exposure to infected bush meat and body fluids of human patients. Ebola and Marburg viruses (EBOV/MARV) cause severe viral hemorrhagic fevers with hematemesis, bloody diarrhea, prostration and case fatality rates of up to $90 \%$ within three days of infection. The EBOV envelope glycoprotein has been used in the VSV-EBOV vaccine, which is $70-100 \%$ effective preventing disease in exposed and vaccinated 
Table 1 The table lists virusspecific compounds in the order of their relevance, detailing compound class, target and stage of development

\begin{tabular}{|c|c|c|c|}
\hline Compound name & Virus/Target & $\begin{array}{l}\text { Paper/ } \\
\text { Author-Date }\end{array}$ & $\begin{array}{l}\text { Regulatory } \\
\text { Approval/ Dev. } \\
\text { Stage }\end{array}$ \\
\hline \multicolumn{4}{|c|}{ Poxviridae- VariolaV, other OPV (Baltimore Group I dsDNA) - section 3.1} \\
\hline Tecovirimat (ST246, TPOXX) & OPV/ F13L - egress & Mucker 2013 & $\begin{array}{l}\text { FDA-appr. } \\
\text { Orthopoxvirus }\end{array}$ \\
\hline Cidofovir & OPV/ Pol & De Clerc 2002 & $\begin{array}{l}\text { FDA-appr. CMV } \\
\text { Compassionate } \\
\text { Use }\end{array}$ \\
\hline Brincidofovir & OPV/ Pol & Parker 2008 & IND \\
\hline Gleevec (STI-571) & OPV/ kinases & Reeves 2005 & $\begin{array}{l}\text { FDA-appr. Cancer } \\
\text { in vitro }\end{array}$ \\
\hline Mitoxandrone & OPV/ unclear & Altmann 2012 & $\begin{array}{l}\text { FDA-appr. Cancer } \\
\text { in vitro }\end{array}$ \\
\hline Olomoucine II & OPV/ kinases & Holcakova 2010 & in vitro \\
\hline Terameprocol & OPV/ unclear & Pollara 2010 & in vitro \\
\hline ddBCNA-cf2642 & $\begin{array}{l}\text { OPV/ membranes, } \\
\text { autophagy }\end{array}$ & McGuigan 2013 & in vitro \\
\hline Bis-benzimides & $\begin{array}{l}\text { OPV/ DNA } \\
\text { intercalators }\end{array}$ & $\begin{array}{l}\text { Yakimovich } \\
2017\end{array}$ & in vitro \\
\hline KPB-100/200 & OPV/ unclear & Cryer 2017 & in vitro \\
\hline FC-6407 & OPV/ D4 & Nuth 2019 & in vitro \\
\hline BB4 D9 & OPV/ unclear & Zanetta 2019 & in vitro \\
\hline \multicolumn{4}{|c|}{ Filoviridae - EBOV, MARV (Baltimore Group V ss-RNA) - section 3.2} \\
\hline Remdesivir (GS-5734) & EBOV/ Pol & Warren 2016 & $\begin{array}{l}\text { IND } \\
\text { in vitro } \\
\text { Phase II clinical } \\
\end{array}$ \\
\hline & & & 2019 \\
\hline Favipiravir (T705) & EBOV/Pol & Bixler 2018a & $\begin{array}{l}\text { appr. in Japan - } \\
\text { Influenza } \\
\text { in vivo }\end{array}$ \\
\hline Galidesivir (BCX4430) & RVFV/ Pol & $\begin{array}{l}\text { Warren } 2014 \\
\text { Taylor } 2016\end{array}$ & $\begin{array}{l}\text { IND } \\
\text { in vivo }\end{array}$ \\
\hline CM-10-18 & $\begin{array}{l}\text { EBOV-MARV/ } \\
\text { a Gluc. } \\
\text { ER enzymes }\end{array}$ & Chang 2013 & in vivo \\
\hline FGI-106 & EBOV/ entry & Aman 2009 & in vitro \\
\hline AR-12 (OSU 03012) & $\begin{array}{l}\text { EBOV-MARV / } \\
\text { PDK-1 }\end{array}$ & Mohr 2015 & in vitro \\
\hline K11777 & EBOV/Prot & Zhou 2015 & in vitro \\
\hline \multicolumn{4}{|c|}{ Alphaviridae - CHIKV, EEEV, VEEV (Baltimore Group IV ss+RNA) - section 3.3} \\
\hline Ribavirin & $\begin{array}{l}\text { CHIKV/ Pol, GTP } \\
\text { depletion, mutagenic }\end{array}$ & Abdelnabi 2015 & $\begin{array}{l}\text { FDA-appr. HCV; } \\
\text { RSV } \\
\text { in vivo }\end{array}$ \\
\hline Sofosbuvir & CHIKV/ Pol & Ferreira 2019 & $\begin{array}{l}\text { FDA-appr. HCV } \\
\text { in vitro }\end{array}$ \\
\hline Favipiravir (T705) & CHIKV/Pol & Abdelnabi 2017 & $\begin{array}{l}\text { appr. in Japan - } \\
\text { Influenza } \\
\text { in vivo }\end{array}$ \\
\hline $\begin{array}{l}\text { Suramin }\left(\text { Germanin }^{\mathrm{TM}},\right. \\
\text { Antrypol }^{\mathrm{TM}} \text { ) }\end{array}$ & CHIKV/ unclear & Kuo 2016 & $\begin{array}{l}\text { FDA-appr. } \\
\text { antiparasitic } \\
\text { in vivo }\end{array}$ \\
\hline
\end{tabular}


Table 1 (continued)

\begin{tabular}{|c|c|c|c|}
\hline Ivermectin & CHIKV/ unclear & Varghese 2016 & $\begin{array}{l}\text { FDA- } \\
\text { anhelmintic } \\
\text { in vitro }\end{array}$ \\
\hline Mefenamic acid & $\begin{array}{l}\text { CHIKV/ elF4E } \\
\text { dephosphorylation }\end{array}$ & Rothan 2016 & $\begin{array}{l}\text { FDA-cancer } \\
\text { in vivo }\end{array}$ \\
\hline Sorafenib & $\begin{array}{l}\text { CHIKV, VEEV, EEEV/ } \\
\text { eIF4E } \\
\text { dephosphorylation }\end{array}$ & Lundberg 2018 & $\begin{array}{l}\text { FDA-cancer } \\
\text { in vitro }\end{array}$ \\
\hline Halofuginone & $\begin{array}{l}\text { CHIKV/ } \\
\text { Protyl tRNAse }\end{array}$ & Hwang 2019 & $\begin{array}{l}\text { Veterinary use } \\
\text { in vitro }\end{array}$ \\
\hline ML-336 & VEEV, EEEV/ Nsp4 & Jonsson 2019 & in vivo \\
\hline LL-37 & VEEV/ entry & Ahmed 2019 & in vitro \\
\hline Compound 25 & CHIKV/nsP2 & Bassetto 2013 & in vitro \\
\hline Prest-37, -392 & $\begin{array}{l}\text { VEEV/ nsP1 capping } \\
\text { enzyme }\end{array}$ & $\begin{array}{l}\text { Ferrera-Ramos } \\
2019\end{array}$ & in vitro \\
\hline Baicalin & CHIKV/ unclear & Oo 2018 & in vitro \\
\hline \multicolumn{4}{|c|}{ Arenaviridae - LassaV, JuninV (Baltimore Group V ss-RNA) - section 3.4} \\
\hline \multirow[t]{2}{*}{ Ribavirin } & LassaV/ & McCormick & FDA-appr. HCV; \\
\hline & $\begin{array}{l}\text { Pol, GTP depletion, } \\
\text { mutagenic }\end{array}$ & 1986 & $\begin{array}{l}\text { RSV } \\
\text { Compassionate } \\
\text { use LassaF } \\
\end{array}$ \\
\hline Favipiravir (T705) & LassaV/ Pol & Rosenke 2018 & $\begin{array}{l}\text { appr. in Japan - } \\
\text { Influenza } \\
\text { in vivo }\end{array}$ \\
\hline LHF 535 & $\begin{array}{l}\text { JuninV/ glycoprotein } \\
\text { GP2 }\end{array}$ & Madu 2018 & in vivo \\
\hline \multicolumn{4}{|c|}{ Bunyaviridae - CCHFV, RVFV, other PhleboV (Baltimore Group V ss-RNA) - section 3.5} \\
\hline Ribavirin & $\begin{array}{l}\text { CCHFV/ Pol, GTP } \\
\text { depletion, mutagenic }\end{array}$ & van Eeden 1985 & $\begin{array}{l}\text { FDA- appr. HCV; } \\
\text { RSV } \\
\text { Compassionate } \\
\text { use CCHF }\end{array}$ \\
\hline Favipiravir (T705) & PhleboV, CCHFV/ Pol & $\begin{array}{l}\text { Gowen } 2010 \\
\text { Hawman } 2018\end{array}$ & $\begin{array}{l}\text { appr. in Japan - } \\
\text { Influenza } \\
\text { in vivo }\end{array}$ \\
\hline Galidesivir & RVFV/ Pol & Westover 2018 & $\begin{array}{l}\text { IND } \\
\text { in vivo }\end{array}$ \\
\hline 2'-Fluoro-2'-deoxycytidine & PhleboV/ Pol & Smee 2018 & in vivo \\
\hline FGI-106 & CCHFV +/ entry & Smith 2010 & in vitro \\
\hline \multicolumn{4}{|c|}{ Flaviviridae - TBEV, DENV, YFV + (Baltimore Group IV ss-RNA) section 3.6} \\
\hline Ribavirin & $\begin{array}{l}\text { YFV +/ } \\
\text { Pol, GTP depletion, } \\
\text { mutagenic }\end{array}$ & Malinoski 1990 & $\begin{array}{l}\text { FDA-appr. HCV; } \\
\text { RSV } \\
\text { Compassionate } \\
\text { use YF }\end{array}$ \\
\hline
\end{tabular}


Table 1 (continued)

\begin{tabular}{|c|c|c|c|}
\hline Sofosbuvir & ZikaV, YFV +/ Pol & $\begin{array}{l}\text { Bullard- } \\
\text { Feibelman } 2017 \\
\text { De Freitas } 2019\end{array}$ & $\begin{array}{l}\text { FDA-appr. HCV } \\
\text { in vivo }\end{array}$ \\
\hline Favipiravir (T705) & UsutuV/ Pol & $\begin{array}{l}\text { Seguera } \\
\text { Guerrero } 2018\end{array}$ & $\begin{array}{l}\text { appr. in Japan - } \\
\text { Influenza } \\
\text { in vivo }\end{array}$ \\
\hline Ivermectine & YFV +/ Helicase & $\begin{array}{l}\text { Mastrangelo } \\
2012\end{array}$ & $\begin{array}{l}\text { FDA-appr. } \\
\text { antihelmintic } \\
\text { in vitro }\end{array}$ \\
\hline Bromocriptine & $\begin{array}{l}\text { ZikaV/ Prot } \\
\text { (Dopamine agonist) }\end{array}$ & Chan 2017 & $\begin{array}{l}\text { FDA-appr. } \\
\text { Diabetes/ } \\
\text { Parkinson } \\
\text { in vitro }\end{array}$ \\
\hline Erythrosin B & DENV +/ Prot & Li 2018 & $\begin{array}{l}\text { FDA-appr. food } \\
\text { additive } \\
\text { in vitro }\end{array}$ \\
\hline Niclosamide & $\begin{array}{l}\text { YFV +/ entry/fusion- } \\
\text { translation }\end{array}$ & Mazzon 2019 & $\begin{array}{l}\text { FDA-appr. } \\
\text { antihelmintic } \\
\text { in vivo }\end{array}$ \\
\hline Galidesivir (BCX4430) & TBEV, WNV / Pol & Eyer 2017 & $\begin{array}{l}\text { IND } \\
\text { in vitro }\end{array}$ \\
\hline \multirow[t]{2}{*}{ AR-12 (OSU 03012) } & ZikaV / PI3K-Akt & Chan 2018 & IND-NSAID \\
\hline & pathway & & in vitro \\
\hline FGI-106 & DENV / entry & Aman 2009 & in vitro \\
\hline $3^{\prime}, 5^{\prime}$-di-O- trityluridine & YFV, DENV / unclear & $\begin{array}{l}\text { De Burghgraeve } \\
2013\end{array}$ & in vitro \\
\hline ddBCNA-cf2642 & $\begin{array}{l}\text { ZikaV/ membranes, } \\
\text { autophagy }\end{array}$ & Nolte 2016 & in vitro \\
\hline NITD008 & DENV/ Pol & Milligan 2018 & in vitro \\
\hline K22 & ZikaV +/ unclear & $\begin{array}{l}\text { García-Nicolás } \\
2018\end{array}$ & in vitro \\
\hline PBTZ 16 & $\begin{array}{l}\text { YFV, TBEV +/ Virus } \\
\text { maturation }\end{array}$ & Cannalire 2019 & in vitro \\
\hline \multicolumn{4}{|c|}{ Orthomyxoviridae - Influenza virus (Baltimore Group V ss-RNA) - section 3.7} \\
\hline $\begin{array}{l}\text { Oeseltamivir, Zanamivir, } \\
\text { Laninamivir, Peramivir }\end{array}$ & $\begin{array}{l}\text { Influenza virus/ } \\
\text { neuraminidase }\end{array}$ & Gubareva 2017 & $\begin{array}{l}\text { FDA-appr. } \\
\text { Influenza }\end{array}$ \\
\hline Baloxavir -Marboxil & $\begin{array}{l}\text { Influenza virus/ } \\
\text { cap dependent } \\
\text { endonuclease (CEN) }\end{array}$ & Noshi 2018 & $\begin{array}{l}\text { FDA-appr. } \\
\text { Influenza }\end{array}$ \\
\hline Favipiravir (T705) & $\begin{array}{l}\text { Influenza virus/ } \\
\text { Pol }\end{array}$ & $\begin{array}{l}\text { Furuta } 2002 \\
\text { Baz } 2018\end{array}$ & $\begin{array}{l}\text { appr. in Japan - } \\
\text { Influenza }\end{array}$ \\
\hline Haloxanide/Nitazoxanide & $\begin{array}{l}\text { Influenza virus/ } \\
\text { HA maturation }\end{array}$ & Tilmanis 2017 & Phase III \\
\hline Cycloheptathiophene & $\begin{array}{l}\text { Influenza virus/ } \\
\text { Pol }\end{array}$ & Nannetti 2019 & in vitro \\
\hline
\end{tabular}


Table 1 (continued)

\begin{tabular}{|l|l|l|l|}
\hline \multicolumn{2}{|l|}{ Paramyxoviridae - MeaslesV, NipahV + (Baltimore Group V ss-RNA) - section 3.8 } \\
\hline Ribavirin & $\begin{array}{l}\text { MeaslesV +/ } \\
\text { Pol, GTP depletion, } \\
\text { mutagenic }\end{array}$ & Jeulin 2009 & $\begin{array}{l}\text { FDA-appr. HCV; } \\
\text { RSV } \\
\text { in vivo }\end{array}$ \\
\hline ERDRP-0519 & MeaslesV/ Pol & Krumm 2014 & in vivo \\
\hline Favipiravir (T705) & NipahV/ Pol & Dawes 2018 & $\begin{array}{l}\text { appr. in Japan - } \\
\text { Influenza } \\
\text { in vivo }\end{array}$ \\
\hline Remdesivir (GS-5734) & NipahV +/ Pol & Lo 2017 & in vitro \\
\hline ddBCNA-cf2642 & $\begin{array}{l}\text { MeaslesV/ } \\
\text { membranes } \\
\text { autophagy }\end{array}$ & McGuigan 2013 & in vitro \\
\hline Droserone & $\begin{array}{l}\text { (Measles virus)/ } \\
\text { unclear }\end{array}$ & Lieberherr 2017 & in vitro \\
\hline $\begin{array}{l}\text { 4'-Azidocytidine (R1479) } \\
\text { Balapiravir }\end{array}$ & NipahV +/ Pol & Hotard 2017 & in vitro \\
\hline \multicolumn{4}{|l|}{} \\
\hline
\end{tabular}

Lead small-molecule drug candidates are highlighted in yellow

Appr. approved, FDA US Food and Drug Administration, IND FDA investigational drug, NHP nonhuman primates, NSAID non-steroidal anti-inflammatory drug, Phase clinical trial phase I to III, Pol viral polymerase, Prot viral protease, Vs. versus, + more viruses, not listed

individuals and has been approved in October 2019 in the EU as the world's first Ebola vaccine [19]. Filoviruses are filamentous enveloped viruses with Group V negativesense single-stranded (ss) RNA genomes. The endosomal Nieman Pick C1 protein, also relevant in flavivirus infections [114] and the TIM-1 (HAVCR1) receptor on the surface of $\mathrm{T}$ cells, also relevant for hepatitis $\mathrm{C}$ virus (HCV) entry [73], are potential targets for antiviral drug development. Anti-filovirus drugs. While treatment recommendations are emphasizing intensive medical support if suitable clinical facilities and cohort isolation are available [15, 16], defense against the use of filoviruses as biological weapons would benefit from an effective virus-targeting therapy. There are currently no licensed antiviral drug treatments for filoviruses. However, in a recent multi-outbreak, multi-country study (PALM- "Together save lives") started in November 2018 in the DRC, two monoclonal antibodies (Mabs) emerged as giving the greatest chance to survive Ebolavirus infection. Zmapp, mAb114 and REGNEB3 were compared to the small-molecule drug remdesivir [150]. The trial was stopped early with REGN-EB3 and $\mathrm{mAb} 114$ giving the greatest chance to survive Ebolavirus infection. The WHO recommends using these two Mabs for all further treatments [150]. Remdesivir (GS5734;1-cyano-substituted adenosine nucleotide analogue), a nucleoside-analogue prodrug and lead compound of the small-molecule antivirals class, has been shown to inhibit EBOV in cell culture and in non-human primates likely by chain termination [144], but showed lower efficacy in the clinical trial compared to monoclonal antibody-based therapeutics. A good alternative, albeit not tested in the
DRC clinical trial, may be T705 (favipiravir; [48]), a repurposed drug synthesized by FUJIFILM-Toyam Chemical Co., licensed for use against influenza virus in Japan, and since found to be a broad-spectrum inhibitor of viral RNA polymerases [34, 49]. T705 and the related pyrazinecarboxamide compounds T-1105 and T-1106 have similar antiviral properties—see also section "Alphaviridae." FDA approval for use of favipiravir to treat filovirus infections is pending. Several animal pilot studies, most recently in non-human primates (NHP), have shown the efficacy of favipiravir [13, 14]). While extensively tested, ribavirin is not FDA approved for EBOV [65]. Other promising candidates (Table 1) are the FGI-106 entry inhibitor [8], CM-10-18-type glycan processing inhibitors, active against Marburg virus and Ebola virus in mouse models [25], a number of kinase inhibitors, including AR-12 (OSU-03012; [24, 102]), and K11777, a protease inhibitor developed for Chagas disease, which has additional activity against SARS-CoV and Ebola virus [154].

\section{Alphaviridae}

Alphaviruses are mosquito-borne viruses, but some can be effectively transmitted via the aerosol route from contaminated rodent feces. Rodents, birds and possibly marine species are maintenance reservoirs [43]. Alphaviruses can cause a number of diseases in humans, including Chikungunya fever, Eastern, Western and Venezuelan equine encephalitis. The handling of the respective viruses requires BLS-3 containment. Two type species, Venezuelan and Eastern Equine Encephalitis viruses (VEEV and EEEV), are considered 
potential biological threat agents [107] with up to $70 \%$ mortality in unprotected populations [142] and represent category B select agents. While human infections with VEEV and EEEV are rare, sporadic and unpredictable but explosive epidemics caused by Chikungunya virus (CHIKV) have occurred in the last decade mainly in South-East Asia and in South America, Central America and the Caribbean, globally amounting to millions of cases. Autochthonous cases of Chikungunya fever have been reported in Italy [93]. Viremia with rashes and fever usually lead to death of cells lining joints, causing arthritis and joint pain. CHIKV infections of neurons can result in potentially fatal encephalitis. Fatal infections, mainly seen in human infants, are rare, but longlasting polyarthralgia and encephalitis cause significant morbidity [95]. Alphaviruses are enveloped viruses with positive-sense ss-RNA genomes. Most experimental antivirals target the viral RNA polymerase. There are no licensed antiviral drugs against alphaviruses causing arthritis and encephalitis, and the treatment of infections is mainly supportive (anti-inflammatory drugs, glucocorticoids). Anti-alphavirus drugs. While pox- and filoviruses are highly lethal biological agents, alphavirus infections are rarely fatal, but can lead to large numbers of incapacitated individuals, due to severe arthralgias and headaches. In this sense, alphaviruses might be effective biological threat agents where incapacitation and saturation of medical care facilities are the goal of a perpetrator (incapacitating agents). Specific antivirals should be able to pass the blood brain barrier (BBB) to control postexposure encephalitis. Intravenous Ribavirin, which is FDA approved for HCV and respiratory syncytial virus (RSV) infection, does not pass the BBB, thus alleviating peripheral symptoms but not providing cure [1,3]. Intranasal ribavirin may be more effective. Ribavirin resolves joint swelling in CHIKV [121], but has no activity against VEEV in vitro [45]. Sofosbuvir, an FDA-approved antiviral drug against $\mathrm{HCV}$, which has been suggested for repurposing against various viruses, has been evaluated for in vitro activity against CHIKV [40]. Among the most promising novel compounds is the broad-spectrum antiviral candidate favipiravir (T-705), initially developed to treat human influenza, which shows a potent antiviral effect in small animal models. The drug is licensed in Japan, while FDA approval is pending [49]. An in vitro comparison between ribavirin and favipiravir revealed that efficacy is cell-type dependent [45]. Efficacy was also shown in a mouse model [2]. Other compounds of interest (Table 1) include drugs approved for other medical conditions and tested for repurposing. Those are the old antiparasitic suramin, which shows ameliorating effects against CHIKV infection in mice [82] and the anthelmintic ivermectin, which shows in vitro activity against a range of alphaviruses [141]. Compounds with known cellular targets include the cancer drugs mefenamic acid and sorafenib, inhibiting replication of CHIKV and other alphaviruses via
eIF4E dephosphorylation in vivo [90, 126], and halofuginone, a prolyl t-RNA synthetase inhibitor in veterinary use that is active in vitro against both alpha- and flaviviruses [66]. Also promising is the virus-specific antiviral ML336 that inhibits Nsp4 of VEEV and EEEV in vivo [72]. Less well-described compounds are LL-37 peptide, an alphavirus entry inhibitor in vitro [4], compound 25 that was identified in silico and optimized to inhibit CHIKV replication in vitro [9], Prest-37 and -392, with in vitro activity against VEEV nsP1 capping enzyme [41], and baicalin, which inhibits CHIKV replication in vitro by interfering with a cellular target [113].

\section{Arenaviridae}

Arenaviruses (Lassa virus-Old World/Junin, Machupo virus-New World) can also cause viral hemorrhagic fevers and are therefore on the list of potential biological threat agents (NATO AMed P-6 [107]; Argentine-Bolivian hemorrhagic fevers). Handling of Lassa virus (LassaV) requires BSL-4 containment. Annual case numbers of Lassa fever (LassaF) are estimated to be between 100.000 and 300.000 in West Africa, but the true public health burden of LassaF is unknown, as are exact case numbers on New World arenavirus infections [147]. Transmitted by aerosolized rodent droppings, arenavirus infections start with a generalized flu-like illness and then cause a range of conditions from aseptic meningitis/encephalitis with choroid plexus infiltration (Lymphocytic Choriomeningitis Virus; LCMV) to potentially fatal hemorrhagic fevers (Lassa, Junin, Guanarito, Machupo, Sabia, and Whitewater Arroyo Virus), with case fatality rates over $30 \%$. Recently a person-to-person transmission of Lassavirus in Germany [148] and an outbreak in Nigeria raised public health concerns. Arenaviruses are enveloped viruses incorporating ribosomes ('arena' in Latin for sand; 'sand'-like appearance of ribosomes in electron microscopy of virus particles, hence arenavirus), with a Group IV genome of two ambisense ss-RNA segments. They use the ubiquitously expressed alpha-dystroglycan as their cellular receptor, and their main cellular targets are antigen-presenting cells. Anti-arenavirus drugs. Ribavirin is used under compassionate use protocols for the treatment of LassaF [97, 112], while recently favipiravir was evaluated and found to enhance survival in cynomolgus (crab-eating) macaques [125]. A further interesting compound is LHF 535, an entry inhibitor targeting arenaviral GP2 [91].

\section{Bunyaviridae}

Human pathogenic bunyaviruses, particularly Hantaviruses and Crimean-Congo Hemorrhagic Fever Virus (CCHFV), can cause hemorrhagic fevers, and CCHFV is on the list of potential biological threat agents (NATO AMed P-6 [107]. 
Handling of these viruses requires BSL-3/BSL-4 containment. Bunyaviruses have a wide host range, including plants, ticks (Hyalomma ticks-CCHFV), insects (Culex-Rift Valley fever virus) and rodents (Hantaviruses), which also serve as transmission vectors. Humans are dead-end hosts, suffering fatal outcomes in the case of Crimean-Congo hemorrhagic fever (CCHF), as well as in hemorrhagic fever with renal syndrome (HFRS; Europe-South-East Asia; Puumala/Hantaan-type viruses) and hantavirus pulmonary syndrome (HPS; Americas; Sin Nombre-type viruses). The clinical outcome is linked to geographical context and the typical animal vector. While high case fatality rates were described with the Korean hantavirus types and with Sin Nombre-type viruses causing HPS in the Americas, the European situation indicates a high case load with HFRS, but less severe clinical outcomes (nephropathia epidemica), caused mainly by Puumala-type viruses [17, 76, 127] as reported by the European Center for Disease Control [38]. Bunyavirus infections are endemic, vector-borne infections. Normally they do not cause epidemics, with the exception of nosocomially transmitted CCHF. Thousands of cases usually occur only in hyperendemic situations over a longer period of time. Beginning with an initial generalized flu-like illness and fever which lasts for about 3 days, these infections can end in fatal hemorrhagic fever (CCHF, HFRS), and pulmonary syndrome (HPS) with a $1-40 \%$ case fatality rate depending on virus strain [71]. Bunyaviruses are enveloped viruses with bi- and tri-segmented ambisense ss-RNA Group IV genomes. Human cellular receptors include human beta 3 integrins, the main human cellular targets are macrophages and endothelial cells, and bunyaviruses replicate in the cytoplasm. No vaccines or licensed treatments are currently available. Anti-bunyavirus drugs. The focus towards the identification of antiviral agents has mostly been on CCHFV infections, which are common in endemic areas, but are either asymptomatic or cause a nonspecific febrile illness that does not require hospitalization or specific treatment. Few patients develop hypotension and hemorrhage, and medical management is then largely supportive, with volume replacement, and prevention of edema and inflammation [68]. Ribavirin has been used to treat CCHF patients under compassionate use protocols with some success since 1985 [140], especially if given early in the course of the infection, but many studies with apparently beneficial results lack controls. Recent randomized clinical trials were unable to show significant beneficial effects of ribavirin versus CCHFV [70, 78]. Further interesting candidates for virus-specific treatment (Table 1) include favipiravir (T-705), which has been evaluated against a number of phleboviruses (PhleboV) and to treat CCHFV infection in rodent models $[53,54,59]$, galidesivir (BCX4430), effective against Rift Valley fever virus (RVFV) infection in a hamster model and investigated for use by the FDA [145], 2'-fluoro-2'-deoxycytidine ( $2 \mathrm{FdC}$ ), which showed protective effects against infections with PhleboV in a rodent model [134], and the FGI-106 entry inhibitor [135].

\section{Flaviviridae}

Flaviviruses causing hemorrhagic fever or severe encephalitis (Omsk hemorrhagic fever, Dengue and Yellow fever, Russian spring-summer encephalitis/Tick Borne Encephalitis (TBEV)) are listed as potential biological threat agents (NATO AMed P-6 [107]) and handling requires BSL-3/ BSL-4 containment. Flaviviruses are arthropod-borne viruses that are endemic worldwide with virus/vector specific geographical distributions, causing regular outbreaks and fatalities, with 30.000 cases/year through yellow fever in Africa alone [51, 149]. Infections with flaviviruses can lead to hemorrhagic fevers (Omsk hemorrhagic fever, yellow fever (YF) and dengue fever with case fatality rates of up to $30 \%$ ) or affect the CNS, causing encephalitis (e.g., Japanese encephalitis, tick borne encephalitis with case fatality rates up to 20\%, Zika and West Nile encephalitis). Human-tohuman transmission is not effective. Live vaccines against yellow fever (17D) and Japanese Encephalitis (JE), a number of inactivated TBEV vaccines, and most recently a live Dengue virus vaccine are available. Flaviviruses are a large family of mosquito- or tick-transmitted enveloped viruses with a Group IV positive-sense single-strand RNA genome, using G-protein coupled receptors for entry into host cells [42]. Anti-flavivirus drugs. Ribavirin is an effective early treatment for yellow fever under compassionate use protocols, but fails to improve survival of dengue infections in nonhuman primates (NHP; [92, 103]. Out of a quite large number of drugs investigated for repurposing against flaviviruses by the FDA (Table 1), the most promising candidate is sofosbuvir [18]. Sofosbuvir was initially developed and approved by FDA for treatment of hepatitis $\mathrm{C}$. It shows activity against a number of flaviviruses in vitro and in the mouse model [33, 105]. Further interesting candidates (13 compounds listed in Table 1) inhibit the viral polymerase [39, 128]), NS2B/NS3 protease and kinases $[23,24])$, cell entry and membrane trafficking [20,109], and other flavivirus targets. The action and the efficacy of most of these compounds in vivo are yet to be determined. The major shortcoming of all candidates so far tested in animal models for the treatment of infections with Usutu (UsutuV), Dengue (DENV) and Zika viruses (ZikaV) is their rather low efficacy $[24,101]$.

\section{Orthomyxoviridae}

Orthomyxoviruses, in particular influenza viruses, although not on top of the list of potential biological threat agents, are fast-moving airborne pathogens capable of causing pandemics with significant mortality. Recombinant influenza 
viruses could be considered as potential biological threat agents. Handling of avian influenza viruses and other influenza viruses with high pathogenic potential requires BSL-3 containment. Pandemic influenza viruses type A are transmitted by the respiratory route to birds and mammals, type B only from human to human, as well as via saliva, nasal secretions, feces and blood, causing acute respiratory distress with potentially fatal outcomes in humans. In humans, infection of the respiratory tract can lead to pneumonia, secondary pneumonia and overwhelming immune responses, followed by multiorgan failure in rare cases. Orthomyxoviruses are globally endemic, and cause sporadic outbreaks, rarely pandemics. Orthomyxoviruses are enveloped viruses with a negative-sense segmented ss-RNA genome. The viral RNA polymerase has a high error rate of $1 / 10,000$. Vaccines are composed of HA/NA subunits (purified from inactivated virions), purified subunits from recombinant sources, or live/ attenuated strains of the endemic strains/subtypes of influenza A virus (currently H1N1 and H3N2), as well as those of influenza B viruses [42]. Anti-orthomyxovirus drugs. FDAapproved neuraminidase inhibitors oseltamivir (Tamifluß), zanamivir (Relenza $\left.{ }^{\circledR}\right)$, laninamivir (Inavir $\left.{ }^{\circledR}\right)$, and peramivir have marginal clinical benefits only when given early but may be useful in severe infections requiring hospitalization/ mechanical ventilation [57]. In 2018 baloxavir-marboxil (Xofluza $\left.{ }^{\circledR}\right)$, an inhibitor of the viral cap-dependent endonuclease (CEN; influenza virus polymerase PA subunit), was approved by the FDA for the treatment of acute, uncomplicated influenza among patients aged 12 years or older $[80,110]$. Favipiravir developed and approved in Japan specifically for treatment of influenza virus infections, and its combination with neuraminidase inhibitors was shown to be effective in a mouse model $[10,48]$. Further interesting candidates are haloxanide/nitazoxanide, thiazolide compounds that were originally developed as antiparasitic agents, but were shown to inhibit influenza virus hemagglutinin maturation and intracellular trafficking of viral components in infected cells and that are now in clinical trials $[83,138]$ as well as cycloheptathiophene-3-carboxamide, which interferes with the polymerase PA-PB1 subunits of influenza virus [106]. Alicyclic amines/aminoadamantanes amantadine and rimantadine, first described in 1985 as M2 protein blockers ([60]; $\mathrm{H}+$ channel/viroporin; only type A viruses), are not recommended anymore for clinical use (WHO/US), due to rapid induction of viral resistance mutations: $100 \%$ of clinical isolates are resistant. A 2014 Cochrane review found no evidence for efficacy or safety of amantadine for the treatment of influenza A [6]. However, their structures may still be useful as scaffolds for the design of future M2 inhibiting drugs.

\section{Paramyxoviridae}

Paramyxoviridae are fast-moving airborne pathogens infecting animals and humans. Hendra $(\mathrm{HeV})$ and Nipah (NiV) viruses, in the genus Henipavirus, are considered zoonotic agents in Australia (horses) and South-East Asia (pigs), respectively. Both viruses may be able to infect other domesticated mammals, and there is a real concern in the veterinary and biodefense communities about spill-over infections and the high fatality rate in humans (632 human NiVcases: $59 \%$ case fatality $[7,131]$. Henipaviruses have so far not caused global epidemics, but due to a high percentage of severe outcomes, as well as lack of vaccines or treatments, $\mathrm{HeV}$ and $\mathrm{NiV}$ are designated biosafety level (BSL-4) agents [106]. They are currently not on the NATO AMed P-6 list of biological threat agents but their potential as agents for bioterrorism has been discussed [84, 89]. Other Paramyxoviruses causing diseases in animals are canine distemper virus (CDV), endemic in Europe (dogs/humans; [11]), Newcastle disease virus affecting birds, and rinderpest virus infecting cattle. Human parainfluenza viruses and respiratory syncytial virus (RSV) are major causes of bronchiolitis, bronchitis and pneumonia in infants and children. Measles (morbilli, rubeola) caused by measles virus (MeaslesV) was responsible for around 733,000 deaths globally in 2000 [22], mostly due to viral pneumonia, secondary bacterial infections due to immune suppression (B cell tropism), and encephalitides [inclusion body encephalitis (MIBE); subacute sclerosing panencephalitis (SSPE)]. A very successful vaccine (MeaslesV strain Edmonston) has been used with the goal to eradicate measles in 2010 [62]. However, anti-vaccine movements have led to the loss of herd immunity and the reemergence of measles in many developed countries [28, 46]. Paramyxoviruses are a family of enveloped viruses with a negative-sense ss-RNA genome (mononegavirales) replicating in the cytoplasm [42]. Anti-paramyxovirus drugs. Ribavirin administered with cyclodextrin has been shown to be effective in a mouse model for measles encephalitis [69]. A very promising candidate antiviral against measles is ERDRP-0519, which has been shown effective against canine distemper virus in a ferret model [81]; however, early resistance development has been described [74]. Favipiravir has a protective effect against Nipah virus infections in the hamster model [29], and remdesivir inhibits a number of paramyxoviruses in vitro [88]. ddBCNAs (see sections "Poxviridae "and "Flaviviridae"; [99]) and the plant extract naphthoquinone droserone have anti-measles activities in vitro [87]. The nucleoside-analogue 4'-azidocytidine (R1479; balapiravir) was developed to inhibit HCV [108], paramyxoviruses, and filoviruses in vitro [63], but showed low efficacy and high toxicity in hepatitis $\mathrm{C}$ patients in early clinical trials [108]. 


\section{Synergy through combination and the use of broad-spectrum antivirals}

Combination treatments with antiviral compounds using different modes of action (MoA) are further increasing efficacy and, by means of individual dose reduction, allow for lower toxicity of the individual compounds. This exploits possible synergies between synthetic small molecules and natural extracts, virus-specific and broad-spectrum agents, and celltargeting compounds. The use and potential benefits of multidrug cocktails, mainly reduction of resistance mutation and toxicity through dose reduction, have been pointed out by many authors, including in the context of yellow fever treatment [103]. Examples for synergistic effects in combinations of antiviral compounds with similar or different MoA are ribavirin with vitamin A in measles infections [12], ribavirin with favipiravir in Zika virus infections [75], and ribavirin with mefenamic acid in infections with Chikungunya virus [126]. Antiviral drug combinations may also be a way to deal with emerging antiviral drug resistance [74].

Broad-spectrum antivirals on the other hand show significant activity against several members of the same or distinct virus families, allowing the empirical treatment of severe viral infections prior to positive diagnosis of the viral agent. Leading examples are at his point the pyrazinecarboxamide compounds T-705 (favipiravir; [2, 7, 48]), $\mathrm{T}-1105$ and $\mathrm{T}-1106$, which are broad-spectrum viral RNA polymerase inhibitors, initially developed for the treatment of influenza virus, and found effective against bunyaviruses [21, 54, 59], alphaviruses [1], filoviruses [13] arenaviruses [125], paramyxoviruses [29], and flaviviruses [128]. A favipiravir resistance mechanism in influenza virus has been described [52]. Other potential broad-spectrum agents are remdesivir (GS-5734), another RNA polymerase inhibitor [137] active against filo-, corona-, and paramyxoviruses [88, 129, 130], FGI-106 with inhibitory activity against filo-, bunya-, and flaviviruses [8], galidesivir (BCX4430) with activity against filo-, bunya-, and flaviviruses [39, 143, 145], $\mathrm{N}^{4}$-hydroxycytidine (NHC) inhibiting influenza-, paramyxo-, flavi-, corona-, as well as alphaviruses [152], and 2'fluoro-2'-deoxycytidine (2'-FdC), which was reported to inhibit various viruses in vitro, including Borna virus, $\mathrm{HCV}$, Lassa virus, certain herpes viruses, and which also inhibits influenza viruses in mice [134]. Previously thought as a onefamily-broad-spectrum compound, sofosbuvir (Sovaldi ${ }^{\mathrm{TM}}$, Soforal ${ }^{\mathrm{TM}}$ ) has in vitro and in vivo activity against several members of the family flaviviridae, and has most recently been shown to be effective against Chikungunya virus [40]. Natural product antivirals are single molecule natural compounds or complex mixtures of organic molecules (e.g., plant extracts) with antiviral activity. Natural product antivirals frequently exhibit broad-spectrum antiviral activity and often a single active compound cannot be identified in extracts [27].

\section{Treatment of viral hemorrhagic fevers (VHF) with ribavirin}

Viral hemorrhagic fevers (VHFs) cause the highest mortality in human hosts of all known viral agents and treatment options are a serious concern both in public health and in biodefense scenarios [67]. If specific antiviral treatment options are not available, supportive care is the mainstay of clinical interventions in VHF, including hemodynamic, hematological, pulmonary and neurological support treatments. Treatment with corticosteroids, vasoactive substances, hemodialysis, and mechanical ventilation saves the patients with the worst clinical symptoms. The only currently widely available antiviral drug, ribavirin, is not approved by the FDA for intravenous application in VHF and is used under compassionate use protocols only. Intravenous ribavirin reduces mortality of HFRS if combined with hemodialysis and both morbidity and mortality in the case of Lassa fever (LassaF). Ribavirin (Copegus ${ }^{\mathrm{TM}}$, Rebetol ${ }^{\mathrm{TM}}$, Virazole ${ }^{\circledR}$ ICN/Valeant (IND)) is used for the treatment of infections with African arenaviruses (Lujo- and Lassa fever) and bunyaviruses (HFRS, Crimean-Congo fever, and Rift Valley fever). However, intravenous ribavirin does not show any benefits for the treatment of any of the VHFs caused by filoviruses, or in infections with RNA viruses causing severe encephalitis $[15,67]$.

\section{Conclusion}

Antiviral drug development is determined by the virus life cycle, both the steps of viral replication per se and the cellular processes supporting viral replication. The action of antivirals targeting a viral replication step may be augmented by an antiviral hitting a different viral target or a cell process, or secondary effects via drug metabolism, resulting in synergy. Most antivirals in the experimental pipeline are either small molecules designed from scaffolds, mostly nucleoside analogues, or natural extracts/complex organic active compounds derived from extracts. The stages of antiviral drug development begin with in silico design and go via testing in single cell types (organotypic cell lines or primary cells) to determine IC50/CC50 =SI, and complex infection models to animal models, clinical trials, and eventually regulatory approval/market. A major hindrance to antivirals development is that of many compounds that show activity in vitro only very few are effective in animal models. Development may also stop for lack of interest and funding. Human organoids/complex in vitro infection models (e.g., barrier models) may provide a bridge to predict activity in clinical trials. 
There are only a small number of antivirals with regulatory approval to treat virus infections, some of which have already been described to select for drug resistant strains. A number of drugs with antiviral activities which are approved for other conditions are being evaluated for repurposing, but the number of compounds currently in the experimental pipeline for clinical testing is small. Consequently, while there are treatment options, they may not be available in sufficient quantity in a biological threat situation. Therefore, research in identification, development, clinical testing and the stockpiling of approved antivirals in sufficient quantities must be a priority for the government actors put in charge of a credible response to deliberate releases of some of the biological agents discussed here. It is well known that even the threat of a biological attack would cause mass hysteria with concomitant economic disruption. Only timely preparation underlined by visible infrastructure, stockpiles of drugs and vaccines, and well-considered emergency plans will allow governments to give the necessary assurances when needed, to avoid negative outcomes [58]. Ideally, research on novel antivirals should also be a priority for research funding and pharmaceutical companies. As long as this is not the case, government funding and research in governmentfunded laboratories in collaboration with specialized university research groups organized in antiviral platforms have to step into the breach, when considerations of market performance and public health priorities are focusing resources elsewhere.

Acknowledgements We thank Dr Romano Silvestri for thoughtful comments and suggestions, and members of the Brancale/Bugert antiviral platform for critical reading of the manuscript.

Funding Funding was provided by Bundeswehr (Grant No. STAN 59-2016-01).

\section{Compliance with ethical standards}

Conflict of interest The authors declare no conflict of interest, particularly, no recommendations regarding priority development of drugs or preferred use are made, except in the context of regulatory approval.

Research involving human and animal rights In this review article, research involving human participants and/or animals is reported and cited.

Informed consent Informed consent was required as per instructions to authors of the respective publishing journals.

\section{References}

1. Abdelnabi R, Neyts J, Delang L (2015) Towards antivirals against chikungunya virus. Antivir Res 121:59-68. https://doi. org/10.1016/j.antiviral.2015.06.017

2. Abdelnabi R, de Morais ATS, Leyssen P, Imbert I, Beaucourt S, Blanc H, Froeyen M, Vignuzzi M, Canard B, Neyts J, Delang L (2017) Understanding the mechanism of the broad-spectrum antiviral activity of favipiravir (T-705): key role of the F1 motif of the viral polymerase. J Virol. https://doi.org/10.1128/JVI.00487 $-17$

3. Abdelnabi R, Jochmans D, Verbeken E, Neyts J, Delang L (2018) Antiviral treatment efficiently inhibits chikungunya virus infection in the joints of mice during the acute but not during the chronic phase of the infection. Antivir Res 149:113-117. https ://doi.org/10.1016/j.antiviral.2017.09.016

4. Ahmed A, Siman-Tov G, Keck F, Kortchak S, Bakovic A, Risner K, Lu TK, Bhalla N, de la Fuente-Nunez C, Narayanan A (2019) Human cathelicidin peptide LL-37 as a therapeutic antiviral targeting Venezuelan equine encephalitis virus infections. Antivir Res 164:61-69. https://doi.org/10.1016/j.antiviral.2019.02.002

5. Altmann SE, Smith AL, Dyall J, Johnson RF, Dodd LE, Jahrling PB, Paragas J, Blaney JE (2012) Inhibition of cowpox virus and monkeypox virus infection by mitoxantrone. Antivir Res 93:305-308. https://doi.org/10.1016/j.antiviral.2011.12.001

6. Alves Galvão MG, Rocha Crispino Santos MA, Alves da Cunha AJ (2014) Amantadine and rimantadine for influenza A in children and the elderly. Cochrane Database Syst Rev 11:745. https ://doi.org/10.1002/14651858.CD002745.pub4

7. Ang BSP, Lim TCC, Wang L (2018) Nipah virus infection. J Clin Microbiol 56:e01875-17. https://doi.org/10.1128/JCM.01875-17

8. Aman MJ, Kinch MS, Warfield K, Warren T, Yunus A, Enterlein S, Stavale E, Wang P, Chang S, Tang Q, Porter K, Goldblatt M, Bavari S (2009) Development of a broad-spectrum antiviral with activity against Ebola virus. Antivir Res 83:245-251. https://doi. org/10.1016/j.antiviral.2009.06.001

9. Bassetto M, De Burghgraeve T, Delang L, Massarotti A, Coluccia A, Zonta N, Gatti V, Colombano G, Sorba G, Silvestri R, Tron GC, Neyts J, Leyssen P, Brancale A (2013) Computer-aided identification, design and synthesis of a novel series of compounds with selective 616 antiviral activity against chikungunya virus. Antivir Res 98:12-18. https://doi.org/10.1016/j.antiv iral.2013.01.002

10. Baz M, Carbonneau J, Rhéaume C, Cavanagh M-H, Boivin G (2018) Combination therapy with oseltamivir and favipiravir delays mortality but does not prevent oseltamivir resistance in immunodeficient mice infected with pandemic A(H1N1) Influenza virus. Viruses. https://doi.org/10.3390/v10110610

11. Andreas Beineke A, Baumgärtner W, Wohlsein P (2015) Crossspecies transmission of canine distemper virus - an update. One Health 1:49-59. https://doi.org/10.1016/j.onehlt.2015.09.002

12. Bichon A, Aubry C, Benarous L, Drouet H, Zandotti C, Parola P, Lagier J-C (2017) Case report: ribavirin and vitamin A in a severe case of measles. Medicine (Baltimore) 96:e9154. https:// doi.org/10.1097/MD.0000000000009154

13. Bixler SL, Bocan TM, Wells J, Wetzel KS, Van Tongeren SA, Dong L, Garza NL, Donnelly G, Cazares LH, Nuss J, Soloveva V, Koistinen KA, Welch L, Epstein C, Liang L-F, Giesing D, Lenk R, Bavari S, Warren TK (2018) Efficacy of favipiravir (T-705) in nonhuman primates infected with Ebola virus or Marburg virus. Antivir Res 151:97-104. https://doi.org/10.1016/j.antiv iral.2017.12.021

14. Bixler SL, Bocan TM, Wells J, Wetzel KS, Van Tongeren SA, Garza NL, Donnelly G, Cazares LH, Soloveva V, Welch L, Epstein C, Liang L-F, Giesing D, Lenk R, Bavari S, Warren 
TK (2018) Intracellular conversion and In vivo dose response of favipiravir (T-705) in rodents infected with Ebola virus. Antivir Res 151:50-54. https://doi.org/10.1016/j.antiviral.2017.12.020

15. Bray M, Paragas J (2002) Experimental therapy of filovirus infections. Antivir Res. https://doi.org/10.1016/S0166-3542(02)00005 $-0$

16. Bray M (2003) Defense against filoviruses used as biological weapons. Antivir Res 57:53-60

17. Bugert JJ, Welzel TM, Zeier M, Darai G (1999) Hantavirus infection-haemorrhagic fever in the Balkans-potential nephrological hazards in the Kosovo war. Nephrol Dial Transpl 14:1843-1844. https://doi.org/10.1093/ndt/14.8.1843

18. Bullard-Feibelman KM, Govero J, Zhu Z, Salazar V, Veselinovic M, Diamond MS, Geiss BJ (2017) The FDA-approved drug sofosbuvir inhibits Zika virus infection. Antivir Res 137:134140. https://doi.org/10.1016/j.antiviral.2016.11.023

19. Callaway E (2019) 'Make Ebola a thing of the past': first vaccine against deadly virus approved. Nature-News. https://doi. org/10.1038/d41586-019-03490-8

20. Cannalire R, Tarantino D, Piorkowski G, Carletti T, Massari S, Felicetti T, Barreca ML, Sabatini S, Tabarrini O, Marcello A, Milani M, Cecchetti V, Mastrangelo E, Manfroni G, Querat G (2019) Broad spectrum anti-flavivirus pyridobenzothiazolones leading to less infective virions. Antivir Res 167:6-12. https:// doi.org/10.1016/j.antiviral.2019.03.004

21. Caroline AL, Powell DS, Bethel LM, Oury TD, Reed DS, Hartman AL (2014) Broad spectrum antiviral activity of favipiravir (T-705): protection from highly lethal inhalational rift valley fever. PLoS Negl Trop Dis 8:e2790. https://doi.org/10.1371/journ al.pntd.0002790

22. CDC (2009) Global measles mortality, 2000-2008. MMWR 58:1321-1326

23. Chan JF-W, Chik KK-H, Yuan S, Yip CC-Y, Zhu Z, Tee K-M, Tsang JO-L, Chan CC-S, Poon VK-M, Lu G, Zhang AJ, Lai K-K, Chan K-H, Kao RY-T, Yuen K-Y (2017) Novel antiviral activity and mechanism of bromocriptine as a Zika virus NS2B-NS3 protease inhibitor. Antivir Res. 141:29-37. https://doi.org/10.1016/j. antiviral.2017.02.002

24. Chan JF-W, Zhu Z, Chu H, Yuan S, Chik KK-H, Chan CC-S, Poon VK-M, Yip CC-Y, Zhang X, Tsang JO-L, Zou Z, Tee K-M, Shuai H, Lu G, Yuen K-Y (2018) The celecoxib derivative kinase inhibitor AR-12 (OSU-03012) inhibits Zika virus via down-regulation of the PI3K/Akt pathway and protects Zika virus-infected A129 mice: a host-targeting treatment strategy. Antivir Res 160:38-47. https://doi.org/10.1016/j.antiviral.2018.10.007

25. Chang J, Warren TK, Zhao X, Gill T, Guo F, Wang L, Comunale MA, Du Y, Alonzi DS, Yu W, Ye H, Liu F, Guo J-T, Mehta A, Cuconati A, Butters TD, Bavari S, Xu X, Block TM (2013) Small molecule inhibitors of ER $\alpha$-glucosidases are active against multiple hemorrhagic fever viruses. Antivir Res 98:432-440. https:// doi.org/10.1016/j.antiviral.2013.03.023

26. Chittick G, Morrison M, Brundage T, Nichols WG (2017) Short-term clinical safety profile of brincidofovir: a favorable benefit-risk proposition in the treatment of smallpox. Antivir Res 143:269-277. https://doi.org/10.1016/j.antiviral.2017.01.009

27. Cryer M, Lane K, Greer M, Cates R, Burt S, Andrus M, Zou J, Rogers P, Hansen MDH, Burgado J, Panayampalli SS, Day CW, Smee DF, Johnson BF (2017) Isolation and identification of compounds from Kalanchoe pinnata having human alphaherpesvirus and vaccinia virus antiviral activity. Pharm Biol 55:1586-1591. https://doi.org/10.1080/13880209.2017.1310907

28. Dahl (1986) MEASLES: a dangerous illness. https://www. encephalitis.info/Handlers/Download.ashx?IDMF=9ea05 8b7-fd6f-493e-8589-34d56e9ac164

29. Dawes BE, Kalveram B, Ikegami T, Juelich T, Smith JK, Zhang L, Park A, Lee B, Komeno T, Furuta Y, Freiberg AN (2018)
Favipiravir (T-705) protects against Nipah virus infection in the hamster model. Sci Rep 8:7604. https://doi.org/10.1038/ s41598-018-25780-3

30. De Burghgraeve T, Selisko B, Kaptein S, Chatelain G, Leyssen P, Debing Y, Jacobs M, Van Aerschot A, Canard B, Neyts J (2013) 3',5'Di-O-trityluridine inhibits In vitro flavivirus replication. Antivir Res 98:242-247. https://doi.org/10.1016/j.antiv iral.2013.01.011

31. De Clercq E (2002) Cidofovir in the treatment of poxvirus infections. Antivir Res 55:1-13

32. De Clercq E, Li G (2016) Approved antiviral drugs over the past 50 years. Clin Microbiol Rev 29:695-747. https://doi. org/10.1128/CMR.00102-15

33. de Freitas CS, Higa LM, Sacramento CQ, Ferreira AC, Reis PA, Delvecchio R, Monteiro FL, Barbosa-Lima G, JamesWestgarth H, Vieira YR, Mattos M, Rocha N, Hoelz LVB, Leme RPP, Bastos MM, Rodrigues GOL, Lopes CEM, Queiroz-Junior CM, Lima CX, Costa VV, Teixeira MM, Bozza FA, Bozza PT, Boechat N, Tanuri A, Souza TML (2019) Yellow fever virus is susceptible to sofosbuvir both in vitro and in vivo. PLoS Negl Trop Dis. 13:7072. https://doi.org/10.1371/ journal.pntd.0007072

34. Delang L, Abdelnabi R, Neyts J (2018) Favipiravir as a potential countermeasure against neglected and emerging RNA viruses. Antivir Res 153:85-94. https://doi.org/10.1016/j.antiv iral.2018.03.003

35. Delaune D, Iseni F, Ferrier-Rembert A, Peyrefitte CN, Ferraris O (2017) The French Armed Forces Virology Unit: a chronological record of ongoing research on orthopoxvirus. Viruses 10:3. https://doi.org/10.3390/v10010003

36. Dixon D (2005) Never come to peace again: Pontiac's uprising and the fate of the British Empire in North America. University of Oklahoma Press, Norman

37. Dyer O (2019) Escalating Congo Ebola epidemic passes 2000 cases amid violence and suspicion. BMJ 365:14062. https://doi. org/10.1136/bmj.14062

38. European Center for Disease Control (ECDC) (2016) Hantavirus infection-Annual Epidemiological Report for 2016. https ://www.ecdc.europa.eu/en/publications-data/hantavirus-infec tion-annual-epidemiological-report-2016

39. Eyer L, Zouharová D, Šrmarová J, Fojtíková M, Štefánik M, Haviernik J, Nencka R, de Clercq E, Růžek D (2017) Antiviral activity of the adenosine analogue BCX4430 against West Nile virus and tick-borne flaviviruses. Antivir Res 142:63-67. https ://doi.org/10.1016/j.antiviral.2017.03.012

40. Ferreira AC, Reis PA, de Freitas CS, Sacramento CQ, Villas Bôas Hoelz L, Bastos MM, Mattos M, Rocha N, Gomes de Azevedo Quintanilha I, da Silva Gouveia Pedrosa C, Rocha Quintino Souza L, Correia Loiola E, Trindade P, Rangel Vieira Y, Barbosa-Lima G, de Castro Faria Neto HC, Boechat N, Rehen SK, Brüning K, Bozza FA, Bozza PT, Souza TML (2019) Beyond members of the Flaviviridae family, Sofosbuvir also inhibits chikungunya virus replication. Antimicrob Agents Chemother. https://doi.org/10.1128/AAC.01389-18

41. Ferreira-Ramos AS, Li C, Eydoux C, Contreras JM, Morice C, Quérat G, Gigante A, Pérez Pérez M-J, Jung M-L, Canard B, Guillemot J-C, Decroly E, Coutard B (2019) Approved drugs screening against the nsP1 capping enzyme of Venezuelan equine encephalitis virus using an immuno-based assay. Antivir Res 163:59-69. https://doi.org/10.1016/j.antiv iral.2019.01.003

42. Fields BN, Knipe DM, Howley PM (2013) Fields virology, 6th edn. Wolters Kluwer Health/Lippincott Williams \& Wilkins, Philadelphia

43. Forrester NL, Palacios G, Tesh RB, Savji N, Guzman H, Sherman M, Weaver SC, Lipkin WI (2012) Genome-scale phylogeny of 
the alphavirus genus suggests a marine origin. J Virol 86:27292738. https://doi.org/10.1128/JVI.05591-11

44. Foster SA, Parker S, Lanier R (2017) The role of brincidofovir in preparation for a potential smallpox outbreak. Viruses. https ://doi.org/10.3390/v9110320

45. Franco EJ, Rodriquez JL, Pomeroy JJ, Hanrahan KC, Brown AN (2018) The effectiveness of antiviral agents with broad-spectrum activity against chikungunya virus varies between host cell lines. Antivir Chem Chemother 26:2040206618807580. https://doi. org/10.1177/2040206618807580

46. Fraser-bell CJ (2019) Global re-emergence of measles update. Glob Biosecur. https://doi.org/10.31646/gbio.43

47. Freestone DS (1985) The need for new antiviral agents. Antivir Res 5:307-324

48. Furuta Y, Takahashi K, Fukuda Y, Kuno M, Kamiyama T, Kozaki K, Nomura N, Egawa H, Minami S, Watanabe Y, Narita $\mathrm{H}$, Shiraki K (2002) In vitro and in vivo activities of anti-influenza virus compound T-705. Antimicrob Agents Chemother 46:977-981

49. Furuta Y, Komeno T, Nakamura T (2017) Favipiravir (T-705), a broad spectrum inhibitor of viral RNA polymerase. Proc Jpn Acad Ser B 93:449-463. https://doi.org/10.2183/pjab.93.027

50. García-Nicolás O, V'kovski P, Vielle NJ, Ebert N, Züst R, Portmann J, Stalder H, Gaschen V, Vieyres G, Stoffel M, Schweizer M, Summerfield A, Engler O, Pietschmann T, Todt D, Alves MP, Thiel V, Pfaender S (2018) The small-compound inhibitor K22 displays broad antiviral activity against different members of the family Flaviviridae and offers potential as a panviral inhibitor. Antimicrob Agents Chemother. https://doi.org/10.1128/ AAC.01206-18

51. Garske T, Van Kerkhove MD, Yactayo S, Ronveaux O, Lewis RF, Staples JE, Perea W, Ferguson NM, Committee Yellow Fever Expert (2014) Yellow fever in Africa: estimating the burden of disease and impact of mass vaccination from outbreak and serological data. PLoS Med 11:e1001638

52. Goldhill DH, te Velthuis AJW, Fletcher RA, Langat P, Zambon M, Lackenby A, Barclay WS (2018) The mechanism of resistance to favipiravir in influenza. PNAS 115:11613-11618

53. Gowen BB, Holbrook MR (2008) Animal models of highly pathogenic RNA viral infections: hemorrhagic fever viruses. Antivir Res 78:79-90. https://doi.org/10.1016/j.antiviral.2007.10.002

54. Gowen BB, Wong M-H, Jung K-H, Smee DF, Morrey JD, Furuta Y (2010) Efficacy of favipiravir (T-705) and T-1106 pyrazine derivatives in phlebovirus disease models. Antivir Res 86:121127. https://doi.org/10.1016/j.antiviral.2009.10.015

55. Grosenbach DW, Honeychurch K, Rose EA, Chinsangaram J, Frimm A, Maiti B, Lovejoy C, Meara I, Long P, Hruby DE (2018) Oral tecovirimat for the treatment of smallpox. N Engl J Med 379:44-53. https://doi.org/10.1056/NEJMoa1705688

56. Grossi IM, Foster SA, Gainey MR, Krile RT, Dunn JA, Brundage T, Khouri JM (2017) Efficacy of delayed brincidofovir treatment against a lethal rabbitpox virus challenge in New Zealand White rabbits. Antivir Res 143:278-286. https://doi.org/10.1016/j.antiv iral.2017.04.002

57. Gubareva LV, Besselaar TG, Daniels RS, Fry A, Gregory V, Huang W, Hurt AC, Jorquera PA, Lackenby A, Leang S-K, Lo J, Pereyaslov D, Rebelo-de-Andrade H, Siqueira MM, Takashita E, Odagiri T, Wang D, Zhang W, Meijer A (2017) Global update on the susceptibility of human influenza viruses to neuraminidase inhibitors, 2015-2016. Antivir Res 146:12-20. https://doi. org/10.1016/j.antiviral.2017.08.004

58. Hawley RJ, Eitzen EM (2001) Biological weapons-a primer for microbiologists. Annu Rev Microbiol 55:235-253. https://doi. org/10.1146/annurev.micro.55.1.235

59. Hawman DW, Haddock E, Meade-White K, Williamson B, Hanley PW, Rosenke K, Komeno T, Furuta Y, Gowen BB, Feldmann
H (2018) Favipiravir (T-705) but not ribavirin is effective against two distinct strains of Crimean-Congo hemorrhagic fever virus in mice. Antivir Res 157:18-26. https://doi.org/10.1016/j.antiv iral.2018.06.013

60. Hay AJ, Wolstenholme AJ, Skehel JJ, Smith MH (1985) The molecular basis of the specific anti-influenza action of amantadine. EMBO J 4:3021-3024

61. Holcakova J, Tomasec P, Bugert JJ, Wang EC, Wilkinson GW, Hrstka R, Krystof V, Strnad M, Vojtesek B (2010) The inhibitor of cyclin-dependent kinases, olomoucine II, exhibits potent antiviral properties. Antivir Chem Chemother 20:133-142. https ://doi.org/10.3851/IMP1460

62. Holzmann H, Hengel H, Tenbusch M, Doerr HW (2016) Eradication of measles: remaining challenges. Med Microbiol Immunol 205:201-208

63. Hotard AL, He B, Nichol ST, Spiropoulou CF, Loa MK (2017) 4-Azidocytidine (R1479) inhibits henipaviruses and other paramyxoviruses with high potency. Antivir Res 2017(144):147-152. https://doi.org/10.1016/j.antiviral.2017.06.011

64. Huggins J, Zhang ZX, Bray M (1999) Antiviral drug therapy of filovirus infections: s-adenosylhomocysteine hydrolase inhibitors inhibit Ebola virus In vitro and in a lethal mouse model. J Infect Dis 179(Suppl 1):S240-S247. https://doi.org/10.1086/514316

65. Huggins JW (1989) Prospects for treatment of viral hemorrhagic fevers with ribavirin, a broad-spectrum antiviral drug. Rev Infect Dis 11(Suppl 4):S750-S761

66. Hwang J, Jiang A, Fikrig E (2019) A potent prolyl tRNA synthetase inhibitor antagonizes Chikungunya and Dengue viruses. Antivir Res 161:163-168. https://doi.org/10.1016/j.antiv iral.2018.11.017

67. Ippolito G, Feldmann H, Lanini S, Vairo F, Di Caro A, Capobianchi MR, Nicastri E (2012) Viral hemorrhagic fevers: advancing the level of treatment. BMC Med. 10:31. https://doi. org/10.1186/1741-7015-10-31

68. Jabbari A, Tabasi S, Abbasi A, Alijanpour E (2012) Crimeancongo hemorrhagic fever: treatment and control strategy in admitted patients. Casp J Intern Med 3:443-444

69. Jeulin H, Venard V, Carapito D, Finance C, Kedzierewicz F (2009) Effective ribavirin concentration in mice brain using cyclodextrin as a drug carrier: evaluation in a measles encephalitis model. Antivir Res 81:261-266. https://doi.org/10.1016/j. antiviral.2008.12.006

70. Johnson S, Henschke N, Maayan N, Mills I, Buckley BS, Kakourou A, Marshall R (2018) Ribavirin for treating Crimean Congo haemorrhagic fever. Cochrane Database Syst Rev. https ://doi.org/10.1002/14651858.CD012713.pub2

71. Jonsson CB, Hooper J, Mertz G (2008) Treatment of hantavirus pulmonary syndrome. Antivir Res 78:162-169. https://doi. org/10.1016/j.antiviral.2007.10.012

72. Jonsson CB, Cao X, Lee J, Gabbard JD, Chu Y-K, Fitzpatrick EA, Julander J, Chung D-H, Stabenow J, Golden JE (2019) Efficacy of a ML336 derivative against Venezuelan and eastern equine encephalitis viruses. Antivir Res 167:25-34. https://doi. org/10.1016/j.antiviral.2019.04.004

73. Kachko A, Costafreda MI, Zubkova I, Jacques J, Takeda K, Wells F, Kaplan G, Major ME (2018) Determinants in the Ig variable domain of human HAVCR1 (TIM-1) are required to enhance hepatitis C virus entry. J Virol 15:92. https://doi.org/10.1128/ jvi.01742-17

74. Kalbermatter D, Shrestha N, Ader-Ebert N, Herren M, Moll P, Plemper RK, Altmann K-H, Langedijk JP, Gall F, Lindenmann U, Riedl R, Fotiadis D, Plattet P (2019) Primary resistance mechanism of the canine distemper virus fusion protein against a small-molecule membrane fusion inhibitor. Virus Res 259:28-37. https://doi.org/10.1016/j.virusres.2018.10.003 
75. Kim J-A, Seong R-K, Kumar M, Shin OS (2018) Favipiravir and ribavirin inhibit replication of Asian and African strains of Zika virus in different cell models. Viruses. https://doi. org/10.3390/v10020072

76. Klempa B, Meisel H, Räth S, Bartel J, Ulrich R, Krüger DH (2003) Occurrence of renal and pulmonary syndrome in a region of northeast Germany where Tula hantavirus circulates. J Clin Microbiol 41(10):4894-4897. https://doi.org/10.1128/ jcm.41.10.4894-4897.2003

77. Koban R, Neumann M, Daugs A, Bloch O, Nitsche A, Langhammer S, Ellerbrok H (2018) A novel three-dimensional cell culture method enhances antiviral drug screening in primary human cells. Antivir Res 150:20-29. https://doi.org/10.1016/j. antiviral.2017.12.005

78. Koksal I, Yilmaz G, Aksoy F, Aydin H, Yavuz I, Iskender S, Akcay K, Erensoy S, Caylan R, Aydin K (2010) The efficacy of ribavirin in the treatment of Crimean-Congo hemorrhagic fever in Eastern Black Sea region in Turkey. J Clin Virol 47:65-68. https://doi.org/10.1016/j.jcv.2009.11.007

79. Kola I, Landins J (2004) Can the pharmaceutical industry reduce attrition rates? Nat Rev Drug Discov 3:711-716. https ://doi.org/10.1038/nrd1470

80. Koszalka P, Tilmanis D, Roe M, Vijaykrishna D, Hurt AC (2019) Baloxavir marboxil susceptibility of influenza viruses from the Asia-Pacific, 2012-2018. Antivir Res 164:91-96. https://doi.org/10.1016/j.antiviral.2019.02.007

81. Krumm SA, Yan D, Hovingh ES, Evers TJ, Enkirch T, Reddy GP, Sun A, Saindane MT, Arrendale RF, Painter G, Liotta DC, Natchus MG, von Messling V, Plemper RK (2014) An orally available, small-molecule polymerase inhibitor shows efficacy against a lethal morbillivirus infection in a large animal model. Sci Transl Med 6:232ra52. https://doi.org/10.1126/scitranslm ed.3008517

82. Kuo S-C, Wang Y-M, Ho Y-J, Chang T-Y, Lai Z-Z, Tsui P-Y, Wu T-Y, Lin C-C (2016) Suramin treatment reduces chikungunya pathogenesis in mice. Antivir Res 134:89-96. https://doi. org/10.1016/j.antiviral.2016.07.025

83. La Frazia S, Piacentini S, Riccio A, Rossignol J-F, Santoro MG (2018) The second-generation thiazolide haloxanide is a potent inhibitor of avian influenza virus replication. Antivir Res 157:159-168. https://doi.org/10.1016/j.antiviral.2018.06.008

84. Lam S-K (2003) Nipah virus-a potential agent of bioterrorism? Antivir Res 57:113-119

85. Levi LI, Vignuzzi M (2019) Arthritogenic alphaviruses: a worldwide emerging threat? Microorganisms. https://doi. org/10.3390/microorganisms7050133

86. Li Z, Sakamuru S, Huang R, Brecher M, Koetzner CA, Zhang J, Chen H, Qin C, Zhang QY, Zhou J, Kramer LD, Menghang $\mathrm{Xi} \mathrm{M}, \mathrm{Li} \mathrm{H}$ (2018) Erythrosin B is a potent and broad-spectrum orthosteric inhibitor of the flavivirus NS2B-NS3 protease. Antivir Res 2018(150):217-225. https://doi.org/10.1016/j. antiviral.2017.12.018

87. Lieberherr C, Zhang G, Grafen A, Singethan K, Kendl S, Vogt V, Maier J, Bringmann G, Schneider-Schaulies J (2017) The plant-derived naphthoquinone droserone inhibits in vitro measles virus infection. Planta Med 83:232-238. https://doi. org/10.1055/s-0042-111825

88. Lo MK, Jordan R, Arvey A, Sudhamsu J, Shrivastava-Ranjan P, Hotard AL, Flint M, McMullan LK, Siegel D, Clarke MO, Mackman RL, Hui HC, Perron M, Ray AS, Cihlar T, Nichol ST, Spiropoulou CF (2017) GS-5734 and its parent nucleoside analog inhibit Filo-, Pneumo-, and Paramyxoviruses. Sci Rep 7:43395. https://doi.org/10.1038/srep43395

89. Luby SP (2013) The pandemic potential of Nipah virus. Antivir Res 100:38-43. https://doi.org/10.1016/j.antiviral.2013.07.011
90. Lundberg L, Brahms A, Hooper I, Carey B, Lin S-C, Dahal B, Narayanan A, Kehn-Hall K (2018) Repurposed FDA-Approved drug sorafenib reduces replication of Venezuelan equine encephalitis virus and other alphaviruses. Antivir Res 157:57-67. https ://doi.org/10.1016/j.antiviral.2018.07.005

91. Madu IG, Files M, Gharaibeh DN, Moore AL, Jung K-H, Gowen BB, Dai D, Jones KF, Tyavanagimatt SR, Burgeson JR, Korth MJ, Bedard KM, Iadonato SP, Amberg SM (2018) A potent Lassa virus antiviral targets an arenavirus virulence determinant. PLoS Pathog 14:e1007439. https://doi.org/10.1371/journ al.ppat.1007439

92. Malinoski FJ, Hasty SE, Ussery MA, Dalrymple JM (1990) Prophylactic ribavirin treatment of dengue type 1 infection in rhesus monkeys. Antivir Res 13:139-149

93. Marano G, Pupella S, Pati I, Masiello F, Franchini M, Vaglio S, Velati C, Liumbruno GM (2017) Ten years since the last Chikungunya virus outbreak in Italy: history repeats itself. Blood Transfus 15:489-490. https://doi.org/10.2450/2017.0215-17

94. Mastrangelo E, Pezzullo M, De Burghgraeve T, Kaptein S, Pastorino B, Dallmeier K, de Lamballerie X, Neyts J, Hanson AM, Frick DN, Bolognesi M, Milani M (2012) Ivermectin is a potent inhibitor of flavivirus replication specifically targeting NS3 helicase activity: new prospects for an old drug. J Antimicrob Chemother 67:1884-1894. https://doi.org/10.1093/jac/dks147

95. Matusali G, Colavita F, Bordi L, Lalle E, Ippolito G, Capobianchi MR, Castilletti C (2019) Tropism of the Chikungunya virus. Viruses. https://doi.org/10.3390/v11020175

96. Mazzon M, Ortega-Prieto AM, Imrie D, Luft C, Hess L, Czieso S, Grove J, Skelton JK, Farleigh L, Bugert JJ, Wright E, Temperton N, Angell R, Oxenford S, Jacobs M, Ketteler R, Dorner M, Marsh M (2019) Identification of broad-spectrum antiviral compounds by targeting viral entry. Viruses. https://doi.org/10.3390/ v11020176

97. McCormick JB, King IJ, Webb PA, Scribner CL, Craven RB, Johnson KM, Elliott LH, Belmont-Williams R (1986) Lassa fever. Effective therapy with ribavirin. N Engl J Med 314:20-26. https://doi.org/10.1056/NEJM198601023140104

98. McGuigan C, Madela K, Aljarah M, Gilles A, Brancale A, Zonta $\mathrm{N}$, Chamberlain S, Vernachio J, Hutchins J, Hall A, Ames B, Gorovits E, Ganguly B, Kolykhalov A, Wang J, Muhammad J, Patti JM, Henson G (2010) Design, synthesis and evaluation of a novel double pro-drug: INX-08189. A new clinical candidate for hepatitis C virus Bioorg. Med Chem Lett 20:4850-4854. https:// doi.org/10.1016/j.bmcl.2010.06.094

99. McGuigan C, Hinsinger K, Farleigh L, Pathirana RN, Bugert JJ (2013) Novel antiviral activity of 1-dideoxy bicyclic nucleoside analogues versus vaccinia and measles viruses in vitro. J Med Chem 56:1311-1322. https://doi.org/10.1021/jm301778x

100. Mercer J, Helenius A (2009) Virus entry by macropinocytosis. Nat Cell Biol 11:510-520. https://doi.org/10.1038/ncb0509-510

101. Milligan GN, White M, Zavala D, Pyles RB, Sarathy VV, Barrett ADT, Bourne N (2018) Spectrum of activity testing for therapeutics against all four dengue virus serotypes in AG129 mouse models: proof-of-concept studies with the adenosine nucleoside inhibitor NITD-008. Antivir Res 154:104-109. https://doi. org/10.1016/j.antiviral.2018.04.012

102. Mohr EL, McMullan LK, Lo MK, Spengler JR, Bergeron É, Albariño CG, Shrivastava-Ranjan P, Chiang C-F, Nichol ST, Spiropoulou CF, Flint M (2015) Inhibitors of cellular kinases with broad-spectrum antiviral activity for hemorrhagic fever viruses. Antivir Res 120:40-47. https://doi.org/10.1016/j.antiv iral.2015.05.003

103. Monath TP (2008) Treatment of yellow fever. Antivir Res 78:116-124

104. Mucker EM, Goff AJ, Shamblin JD, Grosenbach DW, Damon IK, Mehal JM, Holman RC, Carroll D, Gallardo N, Olson VA, 
Clemmons CJ, Hudson P, Hruby DE (2013) Efficacy of Tecovirimat (ST-246) in Nonhuman primates infected with variola virus (smallpox). Antimicrob Agents Chemother 57(12):6246-6253. https://doi.org/10.1128/aac.00977-13

105. Mumtaz N, Jimmerson LC, Bushman LR, Kiser JJ, Aron G, Reusken CBEM, Koopmans MPG, van Kampen JJA (2017) Cell-line dependent antiviral activity of sofosbuvir against Zika virus. Antivir Res. 146:161-163. https://doi.org/10.1016/j.antiv iral.2017.09.004

106. Nannetti G, Massari S, Mercorelli B, Bertagnin C, Desantis J, Palù G, Tabarrini O, Loregian A (2019) Potent and broad-spectrum cycloheptathiophene-3-carboxamide compounds that target the PA-PB1 interaction of influenza virus RNA polymerase and possess a high barrier to drug resistance. Antivir Res 165:55-64. https://doi.org/10.1016/j.antiviral.2019.03.003

107. NATO AMed p-6 (1996) Handbook on the medical aspects of nuclear, biological and chemical (NBC) defensive operationspart II

108. Nelson DR et al (2012) Balapiravir plus peginterferon alfa-2a $(40 \mathrm{KD}) /$ ribavirin in a randomized trial of hepatitis $\mathrm{C}$ genotype 1 patients. Ann Hepatol 11:15-31

109. Nolte J, Cima C, Farleigh L, Narayan R, Friese D, Dobler G, Wölfel S, Brancale A, Bugert JJ (2016) Synergistic effects of novel antivirals Cima 4 and cf2642 on Zika virus. P114. DZIF Annual Meeting: 24-26 Nov 2016, Cologne. https://www.dgidzif-kongress2019.de/assets/bookofabstracts_2016.pdf

110. Noshi T, Kitano M, Taniguchi K, Yamamoto A, Omoto S, Baba K, Hashimoto T, Ishida K, Kushima Y, Hattori K, Kawai M, Yoshida R, Kobayashi M, Yoshinaga T, Sato A, Okamatsu M, Sakoda Y, Kida H, Shishido T, Naito A (2018) In vitro characterization of baloxavir acid, a first-in-class cap-dependent endonuclease inhibitor of the influenza virus polymerase PA subunit. Antivir Res 160:109-117. https://doi.org/10.1016/j.antiviral.2018.10.008

111. Nuth M, Guan H, Xiao Y, Kulp JL, Parker MH, Strobel ED, Isaacs SN, Scott RW, Reitz AB, Ricciardi RP (2019) Mutation and structure guided discovery of an antiviral small molecule that mimics an essential C-Terminal tripeptide of the vaccinia D4 processivity factor. Antivir Res 162:178-185. https://doi. org/10.1016/j.antiviral.2018.12.011

112. Ölschläger S, Neyts J, Günther S (2011) Depletion of GTP pool is not the predominant mechanism by which ribavirin exerts its antiviral effect on Lassa virus. Antivir Res 91:89-93. https://doi. org/10.1016/j.antiviral.2011.05.006

113. Oo A, Rausalu K, Merits A, Higgs S, Vanlandingham D, Bakar SA, Zandi K (2018) Deciphering the potential of baicalin as an antiviral agent for Chikungunya virus infection. Antivir Res 150:101-111. https://doi.org/10.1016/j.antiviral.2017.12.012

114. Osuna-Ramos JF, Reyes-Ruiz JM, Bautista-Carbajal P, Cervantes-Salazar M, Farfan-Morales CN, De Jesús-González LA, Hurtado-Monzón AM, Del Ángel RM (2018) Ezetimibe inhibits dengue virus infection in Huh-7 cells by blocking the cholesterol transporter Niemann-Pick C1-like 1 receptor. Antivir Res 160:151-164. https://doi.org/10.1016/j.antiviral.2018.10.024

115. Parker S, Crump R, Foster S, Hartzler H, Hembrador E, Lanier ER, Painter G, Schriewer J, Trost LC, Buller RM (2014) Coadministration of the broad-spectrum antiviral, brincidofovir (CMX001), with smallpox vaccine does not compromise vaccine protection in mice challenged with ectromelia virus. Antivir Res 111:42-52. https://doi.org/10.1016/j.antiviral.2014.08.003

116. Parker S, Touchette E, Oberle C, Almond M, Robertson A, Trost LC, Lampert B, Painter G, Buller RM (2008) Efficacy of therapeutic intervention with an oral ether-lipid analogue of cidofovir (CMX001) in a lethal mousepox model. Antivir Res. 77:39-49. https://doi.org/10.1016/j.antiviral.2007.08.003

117. Petersen E, Kantele A, Koopmans M, Asogun D, Yinka-Ogunleye A, Ihekweazu C, Zumla A (2019) Human monkeypox: epidemiologic and clinical characteristics, diagnosis, and prevention. Dis Clin N Am, Infect. https://doi.org/10.1016/j. idc.2019.03.001

118. Pires MA, Rodrigues NFS, de Oliveira DB, de Assis FL, Costa GB, Kroon EG, Mota BEF (2018) In vitro susceptibility to ST-246 and Cidofovir corroborates the phylogenetic separation of Brazilian Vaccinia virus into two clades. Antivir Res 152:3644. https://doi.org/10.1016/j.antiviral.2018.02.005

119. Pollara JJ, Laster SM, Petty ITD (2010) Inhibition of poxvirus growth by Terameprocol, a methylated derivative of nordihydroguaiaretic acid. Antivir Res 88:287-295. https://doi. org/10.1016/j.antiviral.2010.09.017

120. Quick J, Loman NJ, Duraffour S, Simpson JT, Severi E, Cowley L, Bore JA, Koundouno R, Dudas G, Mikhail A, Ouédraogo $\mathrm{N}$, Afrough B, Bah A, Baum JH, Becker-Ziaja B, Boettcher J-P, Cabeza-Cabrerizo M, Camino-Sanchez A, Carter LL, Doerrbecker J, Enkirch T, Dorival IGG, Hetzelt N, Hinzmann J, Holm T, Kafetzopoulou LE, Koropogui M, Kosgey A, Kuisma E, Logue CH, Mazzarelli A, Meisel S, Mertens M, Michel J, Ngabo D, Nitzsche K, Pallash E, Patrono LV, Portmann J, Repits JG, Rickett NY, Sachse A, Singethan K, Vitoriano I, Yemanaberhan RL, Zekeng EG, Trina R, Bello A, Sall AA, Faye Ousmane, Faye Oumar, Magassouba N, Williams CV, Amburgey V, Winona L, Davis E, Gerlach J, Washington F, Monteil V, Jourdain M, Bererd M, Camara Alimou, Somlare H, Camara Abdoulaye, Gerard M, Bado G, Baillet B, Delaune D, Nebie KY, Diarra A, Savane Y, Pallawo RB, Gutierrez GJ, Milhano N, Roger I, Williams CJ, Yattara F, Lewandowski K, Taylor J, Rachwal P, Turner D, Pollakis G, Hiscox JA, Matthews DA, O'Shea MK, Johnston AM, Wilson D, Hutley E, Smit E, Di Caro A, Woelfel R, Stoecker K, Fleischmann E, Gabriel M, Weller SA, Koivogui L, Diallo B, Keita S, Rambaut A, Formenty P, Gunther S, Carroll MW (2016) Real-time, portable genome sequencing for Ebola surveillance. Nature 530:228-232. https://doi.org/10.1038/nature16996

121. Ravichandran R, Manian M (2008) Ribavirin therapy for Chikungunya arthritis. J Infect Dev Ctries 2:140-142

122. Reeves P, Bommarius B, Lebeis S, McNulty S, Christensen J, Swimm A, Chahroudi A, Chavan R, Feinberg MB, Veach D, Bornmann W, Sherman M, Kalman D (2005) Disabling poxvirus pathogenesis by inhibition of Abl-family tyrosine kinases. Nature Med 11:731-739. https://doi.org/10.1038/nm1265

123. Reeves $P$, Bommarius B, Lebeis $S$ et al (2005) Disabling poxvirus pathogenesis by inhibition of Abl-family tyrosine kinases. Nat Med 11:1361. https://doi.org/10.1038/nm1205-1361b

124. Robert MA, Christofferson RC, Weber PD, Wearing HJ (2019) Temperature impacts on dengue emergence in the United States: investigating the role of seasonality and climate change. Epidemics. https://doi.org/10.1016/j.epidem.2019.05.003

125. Rosenke K, Feldmann H, Westover JB, Hanley PW, Martellaro C, Feldmann F, Saturday G, Lovaglio J, Scott DP, Furuta Y, Komeno T, Gowen BB, Safronetz D (2018) Use of favipiravir to treat lassa virus infection in macaques. Emerg Infect Dis 24:1696-1699. https://doi.org/10.3201/eid2409.180233

126. Rothan HA, Bahrani H, Abdulrahman AY, Mohamed Z, Teoh TC, Othman S, Rashid NN, Rahman NA, Yusof R (2016) Mefenamic acid in combination with ribavirin shows significant effects in reducing chikungunya virus infection In vitro and In vivo. Antivir Res 127:50-56. https://doi.org/10.1016/j.antiv iral.2016.01.006

127. Schmidt-Chanasit J, Essbauer S, Petraityte R, Yoshimatsu K, Tackmann K, Conraths FJ, Sasnauskas K, Arikawa J, Thomas A, Pfeffer M, Scharninghausen JJ, Splettstoesser W, Wenk M, Heckel G, Ulrich RG (2009) Extensive host sharing of central European tula virus. J Virol 84(1):459-474

128. Segura Guerrero NA, Sharma S, Neyts J, Kaptein SJF (2018) Favipiravir inhibits In vitro Usutu virus replication and delays 
disease progression in an infection model in mice. Antivir Res 160:137-142. https://doi.org/10.1016/j.antiviral.2018.10.026

129. Sheahan TP, Sims AC, Graham RL, et al (2017) Broad-spectrum antiviral GS-5734 inhibits both epidemic and zoonotic coronaviruses. Sci Transl Med 9:eaal3653

130. Sheahan TP, Sims AC, Leist SR, et al (2020) Comparative therapeutic efficacy of remdesivir and combination lopinavir, ritonavir, and interferon beta against MERS-CoV. Nat Commun 11:222

131. Singh RK, Kuldeep Dhama K, Sandip Chakraborty S, Ruchi Tiwari R, Senthilkumar Natesan S, Rekha Khandia R, Ashok Munjal A, Kranti Suresh Vora KS, Latheef SK, Karthik K, Yashpal Singh Malik YS, Rajendra Singh R, Wanpen Chaicumpa W, Mourya DT (2018) Nipah virus: epidemiology, pathology, immunobiology and advances in diagnosis, vaccine designing and control strategies-a comprehensive review. Vet Q 39(1):1875-5941

132. Slusarczyk M, Serpi M, Pertusati F (2018) Phosphoramidates and phosphonamidates (ProTides) with antiviral activity. Antivir Chem Chemoter 26:1-31. https://doi.org/10.1177/2040206618 775243

133. Smee DF, Sidwell RW (2003) A review of compounds exhibiting anti-orthopoxvirus activity in animal models. Antivir Res 57:41-52

134. Smee DF, Jung K-H, Westover J, Gowen BB (2018) 2'-Fluoro$2^{\prime}$-deoxycytidine is a broad-spectrum inhibitor of bunyaviruses In vitro and in phleboviral disease mouse models. Antivir Res 160:48-54. https://doi.org/10.1016/j.antiviral.2018.10.013

135. Smith DR, Ogg M, Garrison A, Yunus A, Honko A, Johnson J, Olinger G, Hensley LE, Kinch M (2010) Development of FGI106 as a broad-spectrum therapeutic with activity against members of the family Bunyaviridae. Virus Adapt Treat 2:9-20. https ://doi.org/10.2147/VAAT.S6903

136. Taylor R, Kotian P, Warren T, Panchal R, Bavari S, Julander J, Dobo S, Rose A, El-Kattan Y, Taubenheim B, Babu Y, Sheridan WP (2016) BCX4430 - a broad-spectrum antiviral adenosine nucleoside analog under development for the treatment of Ebola virus disease. J Infect Public Health 9(3):220-226. https://doi. org/10.1016/j.jiph.2016.04.002

137. Tchesnokov EP, Feng JY, Porter DP, Götte M (2019) Mechanism of inhibition of Ebola virus RNA-dependent RNA polymerase by remdesivir. Viruses. https://doi.org/10.3390/v11040326

138. Tilmanis D, van Baalen C, Oh DY, Rossignol J-F, Hurt AC (2017) The susceptibility of circulating human influenza viruses to tizoxanide, the active metabolite of nitazoxanide. Antivir Res 147:142-148. https://doi.org/10.1016/j.antiviral.2017.10.002

139. Trost LC, Rose ML, Khouri J, Keilholz L, Long J, Godin SJ, Foster SA (2015) The efficacy and pharmacokinetics of brincidofovir for the treatment of lethal rabbitpox virus infection: a model of smallpox disease. Antivir Res 117:115-121. https://doi. org/10.1016/j.antiviral.2015.02.007

140. van Eeden PJ, van Eeden SF, Joubert JR, King JB, van de Wal BW, Michell WL (1985) A nosocomial outbreak of CrimeanCongo haemorrhagic fever at Tygerberg Hospital. Part II. Management of patients. S Afr Med J Suid-Afr Tydskr Vir Geneeskd 68:718-721

141. Varghese FS, Kaukinen P, Gläsker S, Bespalov M, Hanski L, Wennerberg K, Kümmerer BM, Ahola T (2016) Discovery of berberine, abamectin and ivermectin as antivirals against chikungunya and other alphaviruses. Antivir Res 126:117-124. https:// doi.org/10.1016/j.antiviral.2015.12.012

142. Walton TE, Johnson KM (1988) Venezuelan equine encephalomyelitis. In: Monath TP (ed) The Arboviruses: epidemiology and ecology. CRC Press, Boca Raton

143. Warren TK, Wells J, Panchal RG, Stuthman KS, Garza NL, Van Tongeren SA, Dong L, Retterer CJ, Eaton BP, Pegoraro G, Honnold S, Bantia S, Kotian P, Chen X, Taubenheim BR, Welch LS, Minning DM, Babu YS, Sheridan WP, Bavari S (2014)
Protection against filovirus diseases by a novel broad-spectrum nucleoside analogue BCX4430. Nature 508:402-405. https://doi. org/10.1038/nature 13027

144. Warren TK, Jordan R, Lo MK, Ray AS, Mackman RL, Soloveva V, Siegel D, Perron M, Bannister R, Hui HC, Larson N, Strickley R, Wells J, Stuthman KS, Van Tongeren SA, Garza NL, Donnelly G, Shurtleff AC, Retterer CJ, Gharaibeh D, Zamani R, Kenny T, Eaton BP, Grimes E, Welch LS, Gomba L, Wilhelmsen CL, Nichols DK, Nuss JE, Nagle ER, Kugelman JR, Palacios G, Doerffler E, Neville S, Carra E, Clarke MO, Zhang L, Lew W, Ross B, Wang Q, Chun K, Wolfe L, Babusis D, Park Y, Stray KM, Trancheva I, Feng JY, Barauskas O, Xu Y, Wong P, Braun MR, Flint M, McMullan LK, Chen SS, Fearns R, Swaminathan S, Mayers DL, Spiropoulou CF, Lee WA, Nichol ST, Cihlar T, Bavari S (2016) Therapeutic efficacy of the small molecule GS-5734 against Ebola virus in rhesus monkeys. Nature 531:381-385. https://doi.org/10.1038/nature17180

145. Westover JB, Mathis A, Taylor R, Wandersee L, Bailey KW, Sefing EJ, Hickerson BT, Jung K-H, Sheridan WP, Gowen BB (2018) Galidesivir limits Rift Valley fever virus infection and disease in Syrian golden hamsters. Antivir Res 156:38-45. https ://doi.org/10.1016/j.antiviral.2018.05.013

146. Whitehouse ER, Rao AK, Yu YC, Yu PA, Griffin M, Gorman S, Angel KA, McDonald EC, Manlutac AL, Perio MA, McCollum AM, Davidson W, Wilkins K, Ortega E, Satheshkumar PS, Townsend MB, Isakari M, Petersen BW (2019) Novel treatment of a vaccinia virus infection from an occupational needlestickSan Diego, California. MMWR Morb Mortal Wkly Rep 68:943946. https://doi.org/10.15585/mmwr.mm6842a2

147. WHO Roadmap to Nectected Tropical Diseases (2012) https:// unitingtocombatntds.org/wp-content/uploads/2017/11/who_ntd_ roadmap.pdf

148. WHO (2016) Lassa fever in Germany. https://www.who.int/csr/ don/23-march-2016-lassa-fever-germany/en/

149. WHO (2018) A global strategy to eliminate yellow fever epidemics 2017-2026. World Health Organization, Geneva

150. WHO (2019) Update on ebola drug trail. https://www.who.int/ news-room/detail/11-08-2019-update-on-ebola-drug-trial-twostrong-performers-identified; https://www.niaid.nih.gov/newsevents/independent-monitoring-board-recommends-early-termi nation-ebola-therapeutics-trial-drc

151. Yakimovich A, Huttunen M, Zehnder B, Coulter LJ, Gould V, Schneider C, Kopf M, McInnes CJ, Greber UF, Mercer J (2017) Inhibition of poxvirus gene expression and genome replication by bisbenzimide derivatives. J Virol 91:e0838-17. https://doi. org/10.1128/jvi.00838-17

152. Yoon J-J, Toots M, Lee S, Lee M-E, Ludeke B, Luczo JM, Ganti K, Cox RM, Sticher ZM, Edpuganti V, Mitchell DG, Lockwood MA, Kolykhalov AA, Greninger AL, Moore ML, Painter GR, Lowen AC, Tompkins SM, Fearns R, Natchus MG, Plemper RK (2018) Orally efficacious broad-spectrum ribonucleoside analog inhibitor of influenza and respiratory syncytial viruses. Antimicrob Agents Chemother 62:e00766-18. https://doi.org/10.1128/ AAC.00766-18

153. Zanetta P (2019) Dandelion extract BB4 D9 shows antiviral activity versus orthopoxviruses. Dissertation for the Master of Science in Biology. University of Milano-Bicocca and MBDC-2018-GO5

154. Zhou Y, Vedantham P, Lu K, Agudelo J, Carrion R, Nunneley JW, Barnard D, Pöhlmann S, McKerrow JH, Renslo AR, Simmons G (2015) Protease inhibitors targeting coronavirus and filovirus entry. Antivir Res 116:76-84. https://doi.org/10.1016/j. antiviral.2015.01.011

Publisher's Note Springer Nature remains neutral with regard to jurisdictional claims in published maps and institutional affiliations. 